\title{
Effects of pharmaceuticals on the nitrogen cycle in water and soil: a review
}

\author{
Reza Pashaei $₫$ - Pari Zahedipour-Sheshglani $₫$ • \\ Reda Dzingelevičienè ${ }^{\circledR} \cdot$ Sajjad Abbasi ${ }^{\mathbb{D}}$. \\ Robert M. Rees $(\mathbb{D}$
}

Received: 12 October 2021 / Accepted: 31 December 2021 / Published online: 19 January 2022

(C) The Author(s), under exclusive licence to Springer Nature Switzerland AG 2022

\begin{abstract}
The effects of pharmaceuticals on the nitrogen cycle in water and soil have recently become an increasingly important issue for environmental research. However, a few studies have investigated the direct effects of pharmaceuticals on the nitrogen cycle in water and soil. Pharmaceuticals can contribute to inhibition and stimulation of nitrogen cycle processes in the environment. Some pharmaceuticals have no observable effect on the nitrogen cycle in water and soil while others appeared to inhibit or stimulate for it. This review reports on the most recent evidence of effects of pharmaceuticals on the nitrogen cycle processes by examination of the potential impact of pharmaceuticals on nitrogen fixation, nitrification, ammonification, denitrification, and anammox. Research studies have identified pharmaceuticals that
\end{abstract}

R. Pashaei $(\bowtie) \cdot$ R. Dzingelevičienè

Marine Research Institute of Klaipeda University,

Klaipeda, Lithuania

e-mail: reza.pashaei@ku.lt; reza.pashaei@v.umk.pl

R. Dzingelevičienè

e-mail: reda.dzingeleviciene@ku.lt

R. Pashaei

Department of Environmental Chemistry and Bioanalytics, Faculty of Chemistry, Nicolaus Copernicus University, Torun, Poland

P. Zahedipour-Sheshglani

Department of Horticulture, Agriculture Faculty, Urmia

University, Nazloo Ave., 144, Urmia, Iran

e-mail: p.zahedipour@urmia.ac.ir can either inhibit or stimulate nitrification, ammonification, denitrification, and anammox. Among these, amoxicillin, chlortetracycline, ciprofloxacin, clarithromycin, enrofloxacin, erythromycin, narasin, norfloxacin, and sulfamethazine had the most significant effects on nitrogen cycle processes. This review also clearly demonstrates that some nitrogen transformation processes such as nitrification show much higher sensitivity to the presence of pharmaceuticals than other nitrogen transformations or flows such as mineralization or ammonia volatilization. We conclude by suggesting that future studies take a more comprehensive approach to report on pharmaceuticals' impact on the nitrogen cycle process.

Keywords Pollution $\cdot$ Pharmaceuticals $\cdot$ Nitrogen transformation $\cdot$ Agriculture $\cdot$ Antibiotics

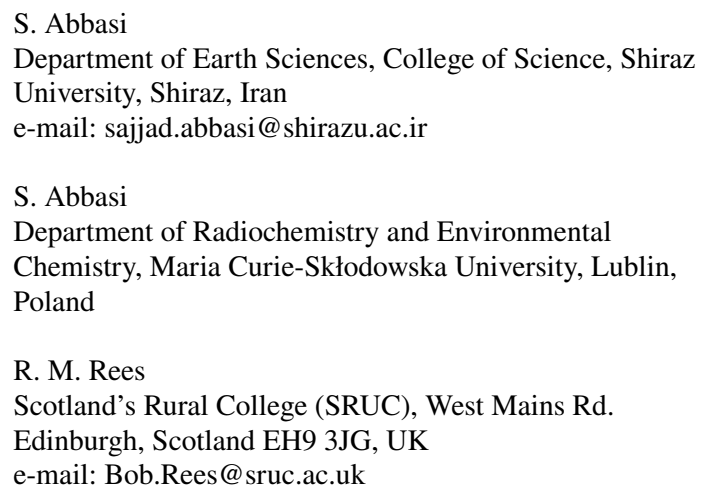




\section{Introduction}

Societies around the world are placing increasing emphasis on managing and enhancing water, soil, and air quality in order to achieve widely shared sustainability goals (Folke et al., 2021). Maintaining water quality in marine ecosystems has become a critical focus of environmental management (Pashaei et al., 2015), and the importance of soil quality is rapidly emerging as a key indicator of sustainable land management practices (Sofo et al., 2021). However, emerging pollutants such as pharmaceuticals pose a significant threat. Pharmaceutical consumption has increased significantly in recent decades, and they are now used for a wide range of therapeutic purposes; however, pharmaceutical compounds in wastewater, sewage sludge, and manure are transported to terrestrial and aquatic ecosystems via a range of pathways including disposal, discharge, and use as fertilizer amendments (DeVries \& Zhang, 2016). Within both aquatic and terrestrial environments, pharmaceutical products can have negative impacts on the nitrogen cycle and therefore impact on soil fertility, crop nutrition, and the wider transformations of nitrogen in our environment. For instance, fluoroquinolones and sulfonamides have been shown to partially inhibit denitrification in the environment, and the application of swine manure containing the antibiotic tylosin to soil has been shown to change the nitrogen behaviour mediated by these microbial communities (Grenni et al., 2018; Laverman et al., 2015; Roose-Amsaleg \& Laverman, 2016).

Human activities have already caused severe imbalances in the global nitrogen cycle, which is an essential part of the global biogeochemical cycle (Hao et al., 2021). Nitrogen is the fourth most abundant element in cellular biomass and is required by all living organisms, accounting for $1-4 \%$ of living cells (Hirsch \& Mauchline, 2015; Woodmansee et al., 1978). In both terrestrial and aquatic ecosystems, nitrogen plays an important role (Li et al., 2021; Zhang et al., 2019a). Currently, industrial fertilizers are used to produce food for about half of the world's population, and fertilizer use and legume cultivation have nearly doubled nitrogen input to terrestrial and marine ecosystems (Galloway et al., 2013; Kuypers et al., 2018). Nitrogen exists in the soil mostly in the form of organic compounds, which plants require for growth but organic-N cannot be directly utilized by plants because it must first be converted to ammonium or nitrate ions before it can be absorbed. The transformations of nitrogen in the environment collectively known as the nitrogen cycle result from a wide range of transformations including nitrogen fixation, assimilation, nitrification, and denitrification (Fig. 1). Biologically available or reactive nitrogen is derived from both abiotic (approximately 3\% from lightning and $30 \%$ from the fertilizer industry) and biotic inputs via biological nitrogen fixation mediated by diazotrophic bacteria (approximately 67\% from both marine and terrestrial ecosystems) (Behar et al., 2005; Fowler et al., 2015; Nardi et al., 2002). The transformations of nitrogen play an important role in the nutrition of organisms and microorganisms. As a result, nitrogen is crucial in regulating primary production in the biosphere (Gruber \& Galloway, 2008). However, nitrogen also represents a significant threat to the sustainable management of land, air, and water since nitrogen contained in fertilizers and manures is easily lost to the environment causing a wide range of negative impacts including greenhouse gas emissions, damage to air quality, water quality and soil quality, and a loss of biodiversity (Sutton et al., 2011). This review investigates the effects of pharmaceuticals on the nitrogen cycle in water, soil, and associated environmental issues.

\section{Nitrogen cycle}

The aquatic and terrestrial environments are the two most important reservoirs of reactive nitrogen. At a global scale, the main inputs to reservoirs of reactive nitrogen are biological $\mathrm{N}$ fixation and the industrial manufacture of fertilizer nitrogen. These processes contribute to an annual addition of reactive $\mathrm{N}$ to the biosphere of fixed $\mathrm{N}$ of over $450 \mathrm{Tg} \mathrm{N}$ per year (Fowler et al., 2015). The residence time of this nitrogen in terrestrial and aquatic environments varies considerably, but the return of dinitrogen to the atmosphere from these environments is achieved by the microbial reduction of nitrate in soils and water to dinitrogen gas. The large uncertainties associated with estimates of biological $\mathrm{N}$ fixation and denitrification at a global scale make it difficult to determine whether these processes are currently balanced (Galloway et al., 2004; Vitousek et al., 2013). 
Fig. 1 Nitrogen cycle process

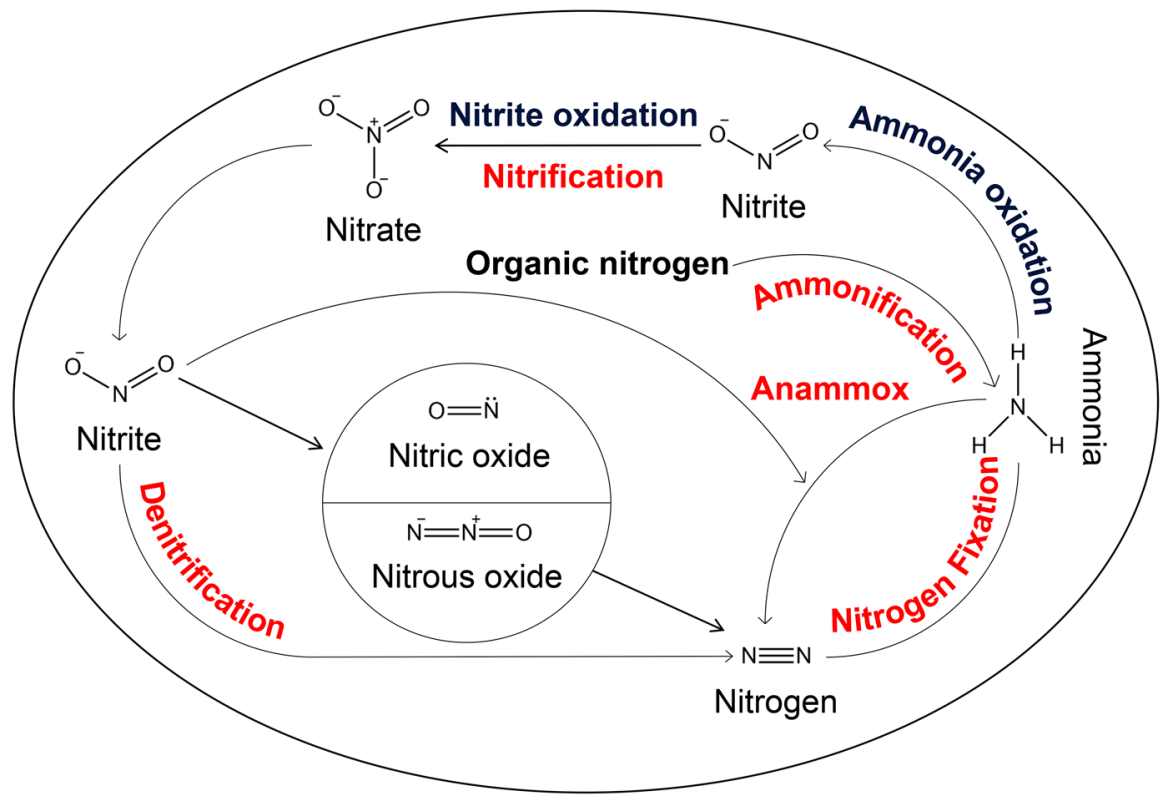

Nitrogen cycle in water

The availability of inorganic and organic nitrogen compounds, primarily nitrate, ammonium, and dissolved organic nitrogen (DON) drives primary production in the oceans to a large extent (Voss et al., 2013). The nitrogen cycle in water is driven by complex biogeochemical transformations mediated by microorganisms, such as nitrogen fixation, denitrification, and assimilation, as well as anaerobic ammonia oxidation (Zehr \& Kudela, 2011). Nitrogen reduction to ammonia is one of the most remarkable reactions catalysed by living organisms (a process known as nitrogen fixation) and a critical reaction in the nitrogen cycle (Rosca et al., 2009). The magnitude of biological nitrogen fixation and denitrification in the ocean, as well as the corollary question of how well these two processes balance each other, is currently hotly debated (Gruber \& Galloway, 2008). Biological nitrogen fixation (BNF) is carried out by free living prokaryotes (bacteria) and a specialized group of symbiotic prokaryotes associated with leguminous plants.

Nitrogen cycle in soil

Nitrogen is a key nutrient needed by plants, and, as a result, we use around $120 \mathrm{Tg}$ of synthetically produced $\mathrm{N}$ fertilizers on an annual basis to support crop production (Gerten et al., 2020). This is supplemented by inputs of nitrogen provided by $88 \mathrm{Tg}$ from BNF which in terrestrial environments is largely produced by leguminous plants (Davies-Barnard \& Friedlingstein, 2020). The recent realization that the response of ecosystems to global environmental change will be heavily reliant on nitrogen dynamics has sparked renewed interest in the soil nitrogen cycle (Luo et al., 2011; Van Groenigen et al., 2006, 2015). Three characteristics of reactive nitrogen are of particular relevance to processes of transformation in soils: (1) the abundance of protein-based compounds in plants and soils, (2) the nature of the $\mathrm{C}-\mathrm{N}$ bond in organic matter, litter and soil, and (3) the stoichiometry of various groups of organisms within ecosystems (Vitousek et al., 2002).

The characteristics of pharmaceuticals that impact on the nitrogen cycle

The nitrogen cycle in water and soil is being altered by pharmaceutical compounds, which are emerging pollutants. Many drugs, owing to their widespread human and veterinary usage, are being continuously added to ecosystems and can exhibit pseudo-persistence (Radke et al., 2010), and recently, widespread pharmaceutical detection in terrestrial and aquatic systems has sparked significant scientific and regulatory concern (Barra Caracciolo et al., 2015; Cardoso et al., 2014; 
Zuccato et al., 2010). During this time, pharmaceutical consumption, particularly during the COVID-19 epidemic, such as chloroquine, dexamethasone, favipiravir, hydroxychloroquine, lopinavir, oseltamivir, ribavirin, teicoplanin, and umifenovir, has increased, which has potentially significant implications for the nitrogen cycle process (Fig. 2). Pharmaceuticals differ from other chemical contaminants in the following ways: (1) they can be formed by an infinite number of complex molecules that differ in molecular weight, structure, functionality, and form; (2) they have the ability to pass through cellular membranes and, as a result, are relatively persistent if they are not inactivated before achieving the desired therapeutic effect; (3) they are polar molecules with more than one ionizable group, and their degree of ionization, among other things, is affected by the medium's $\mathrm{pH}$; (4) they are lipophilic and some are water-soluble; (5) drugs such as erythromycin, naproxen, and sulfamethoxazole can remain in the environment for more than a year; others, such as clofibric acid, can remain in the environment for several years and become biologically active due to accumulation; (6) following administration, the molecules are absorbed, distributed, and subjected to metabolic reactions that can change their chemical structure (Quesada et al., 2019); and (7) plastic particles can be absorbed by pharmaceutical compounds, increasing toxicity. Antibiotics are one of the most common pharmaceutical types found in high concentrations in water and soil. Antibiotic concentrations in natural environments, such as soil or water, range from a few nanograms per litre or kilogram of soil to hundreds of nanograms per litre or kilogram of soil, and the highest concentrations are typically found in areas subjected to high anthropogenic pressures, such as hospital effluents, wastewater influents, and effluents, and soils treated with manure or soils used for livestock (Grenni et al., 2018; Kay et al., 2004; Ory et al., 2016; Patrolecco et al., 2015; Verlicchi et al., 2015).

\section{Nitrogen fixation}

Biological $\mathrm{N}$ fixation (BNF) is a microbial process that converts molecular $\mathrm{N}_{2}$ gas to reactive, biologically available nitrogen forms (Marino \& Howarth, 2009). Nitrogen fixation occurs when atmospheric nitrogen is converted to ammonia by nitrogenase, a pair of bacterial enzymes found in a few bacteria species, including cyanobacteria. However, most BNF is undertaken by Rhizobium bacteria which form a symbiotic relationship with leguminous plants (Herridge et al., 2008). Legumes not only are widely cultivated crop plants but also exist extensively in all ecosystems. The nitrogen fixed by biological fixation is first used to create ammonium $\left(\mathrm{NH}_{4}{ }^{+}\right)$ions which are subsequently incorporated into amino acids (Abu Shmeis, 2018).

\section{Nitrogen fixation in water}

Most of the reactive nitrogen in inland aquatic ecosystems comes from diffuse sources within the landscape
Fig. 2 The negative impact of pharmaceuticals on the nitrogen cycle process in water and soil

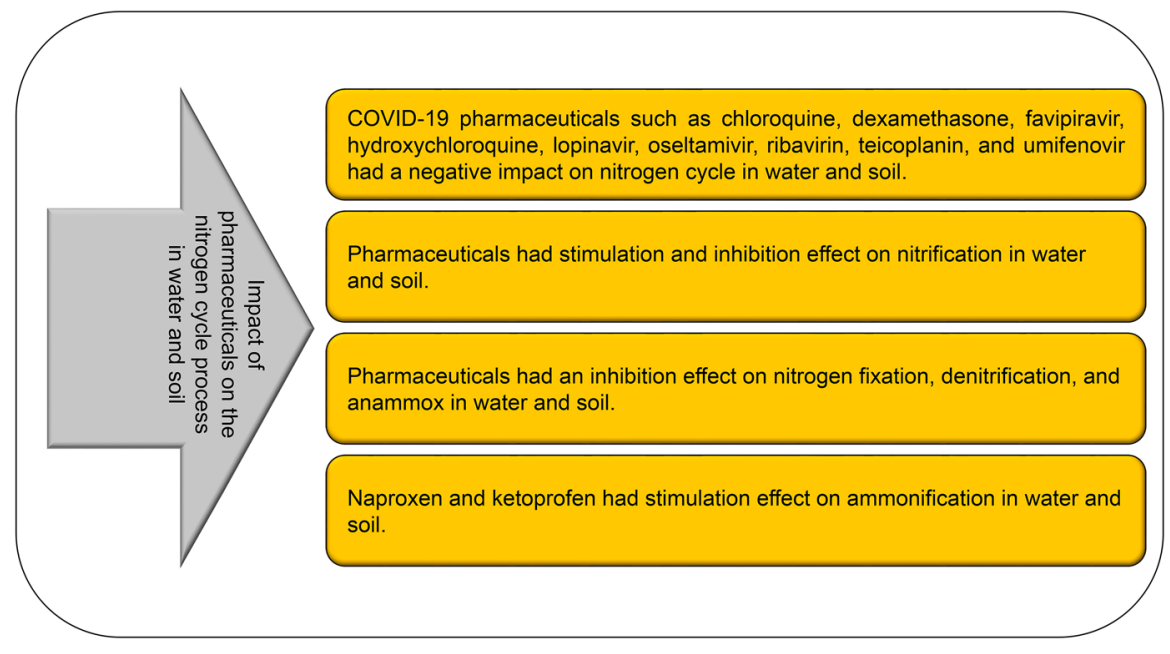


ecosystems (via nitrate leaching), usually originating either directly or indirectly from the use of fertilizers or manures. However, BNF can also provide significant nitrogen inputs (Marino \& Howarth, 2014). In aquatic environments, a wide range of prokaryotic organisms capable of nitrogen fixation exist, including bacteria that use organic carbon (heterotrophs), photosynthetic bacteria that fix inorganic carbon into biomass (autotrophs), and cyanobacteria (photoautotrophs) (Marino \& Howarth, 2009). Although heterotrophs constitute a significant sink for primary production and thus an essential component of the marine nitrogen cycle (Berges \& Mulholland, 2008), autotrophs while cyanobacteria also play a unique ecological role in aquatic ecosystems because they are the only organisms on Earth capable of fixing both inorganic carbon and nitrogen in an oxic (oxygencontaining) environment (Marino \& Howarth, 2009). Marino and Howarth (2014) found that heterotrophic bacteria and cyanobacteria are responsible for most nitrogen fixation in inland waters. Nitrogen fixation in reef ecosystems is a good example of nitrogen fixation in aquatic environments. Nitrogen fixation has since been proposed as a prominent component of the nitrogen cycle on coral reefs that may relieve $\mathrm{N}$ limitation and contribute significantly to overall marine N inputs (O’Neil \& Capone, 2008).

\section{Nitrogen fixation in soil}

Nitrogen fixation in the soil can occur in a variety of ways, including anthropogenic processes, bacteria, etc. Biological nitrogen fixation is carried out by some free living microorganisms known as diazotrophs, such as Clostridium bacteria, which can be found in anaerobic soil environments, and oxygenic bacteria such as the cyanobacteria that are able to both fix nitrogen and carbon through photosynthesis. However, more important in most soils are the inputs of biologically fixed $\mathrm{N}$ by the Rhizobium bacteria which exist in symbiotic relationships within root nodules leguminous plant species (Sprent et al., 2017). In more intensively managed agricultural soils, the inputs of synthetic fertilizers have been used to replace biological inputs for the production of food crops and forage (Van den Berg \& Ashmore, 2008). Pharmaceutical contamination that is related to human activities can however inhibit BNF in soil. According to Gomes et al. (2018), rates of photosynthesis, nitrogen-fixation, and assimilation were reduced with increased hydrogen peroxide accumulation by the presence of ciprofloxacin in the plants.

Effects of pharmaceuticals on the nitrogen fixation

Pharmaceuticals, temperature, and light, as well as soil acidity, alkalinity, salinity, phosphorus, and water content status, all have a significant impact on BNF (Nandanwar et al., 2020). The potential impact of antibiotics on environmental bacteria is of significant concern, both from the perspective of enhancing the environmental reservoir of antibiotic resistance (the resistome) and through the inhibition of microorganisms that carry out important ecosystem services (Boxall, 2004; Brandt et al., 2015; Durso \& Cook, 2014; Finley et al., 2013; Gaze et al., 2013; Griffiths \& Philippot, 2013; Kumar et al., 2005; Revellin et al., 2018), especially for nitrogen fixation.

\section{Nitrification}

Nitrification takes place in soils, sediments, and aquatic environments (Butterbach-Bahl et al., 2011), and it is an oxidation process of converting ammonia $\left(\mathrm{NH}_{3}\right)$ to nitrite $\left(\mathrm{NO}_{2}^{-}\right)$and then to nitrate $\left(\mathrm{NO}_{3}{ }^{-}\right)($Casciotti et al., 2011). Ammonia oxidation $\left(\mathrm{NH}_{3} \rightarrow \mathrm{NO}_{2}^{-}\right)$and nitrite oxidation $\left(\mathrm{NO}_{2}{ }^{-} \rightarrow \mathrm{NO}_{3}{ }^{-}\right)$are two consecutive nitrification steps, undertaken by two physiologically distinct clades of ammonia-oxidizing bacteria (AOB) and nitrite-oxidizing bacteria (NOB), whose close collaboration is required for complete ammonia-to-nitrate conversion (Hu \& He, 2017). The ammonia-oxidizing bacteria, ammonia-oxidizing archaea, and nitriteoxidizing bacteria are all autotrophic microorganisms that perform the nitrification process as well as nitrification, unlike ammonification and denitrification, that is performed by a small number of organisms (Prosser, 2007).

$\mathrm{NH}_{4}^{+}+\mathrm{O}_{2}+\mathrm{H}^{+} \rightarrow \mathrm{NH}_{2} \mathrm{OH}+\mathrm{H}_{2} \mathrm{O}$

$\mathrm{NH}_{2} \mathrm{OH}+\mathrm{H}_{2} \mathrm{O} \rightarrow \mathrm{NO}_{2}^{-}+5 \mathrm{H}^{+}$

Nitrification in water

Nitrification has particular importance in aquatic environments. Nitrification reduces the demand for 
nitrogenous oxygen in wastewater effluents, and nitrification is essential in wastewater treatment because it aids in the removal of ammonia, which is toxic to many fish (Ergas \& Aponte-Morales, 2014). Nitrification is the final step in the regeneration of inorganic nitrogen from organic matter decomposition in the ocean, and it is tightly linked to organic matter flux in the water column and the majority of nitrification takes place near the surface layer namely the euphotic zone (Ward, 2011; Ward \& Zafiriou, 1988). Nitrification rates in aquatic environments are determined by environmental factors such as salinity, temperature, oxygen, and $\mathrm{pH}$. Nitrification in the water relies heavily on ammonia oxidation. Because many pharmaceuticals are often compounds that are resistant to biodegradation, their presence in raw sewage may have an impact on the performance of sensitive sewage treatment plant (STP) processes such as nitrification (Dokianakis et al., 2004). Ammonia-oxidizing bacteria $(\mathrm{AOB})$ can be used for the removal of pharmaceutical residues which have become an emerging threat to the aquatic system in the last decades (Soliman \& Eldyasti, 2018). Another study found that Nitrosomonas europaea and mixed ammonia-oxidizing bacteria (AOB) in nitrifying activated sludge could degrade triclosan and bisphenol A, but only mixed cultures could degrade ibuprofen, demonstrating that ammonia-oxidizing bacteria (AOB) can remove pharmaceutical residues whether in pure or mixed cultures (Roh et al., 2009; Soliman \& Eldyasti, 2018). An important example of the negative impact of pharmaceuticals on the nitrogen cycle is related to nitrification and denitrification. Barra Caracciolo et al. (2015) determined that at $250 \mathrm{mg} / \mathrm{L}$ concentrations, acetaminophen had a significant inhibitory effect $(>25 \%)$ on nitrification and denitrification rates.

\section{Nitrification in soil}

Nitrification, or the oxidation of $\mathrm{NH}_{4}^{+}$to $\mathrm{NO}_{3}{ }^{-}$, occurs readily in oxic environments such as welldrained soils due to the activity of nitrifying prokaryotes, and this process is important for soil fertility because nitrate is easily assimilated by plants (Ergas \& Aponte-Morales, 2014; Zhu et al., 2019). A range of conditions, such as soil temperature, moisture, and $\mathrm{pH}$, influences rates of nitrification to occur in the soil (Izaurralde et al., 2012). However, nitrification in soil with low pH can occur (Hu et al., 2014). Soil, oxygen status, and ammonium concentrations play important role in rates of nitrification (Baggs et al., 2010; Butterbach-Bahl et al., 2013; Zhu et al., 2019). The ammonia oxidation pathway is the first and rate-limiting step in nitrification, converting ammonia to nitrite, and it is the primary contributor to the ammonium:nitrate balance in the soil (Beeckman et al., 2018; Kowalchuk \& Stephen, 2001).

\section{Effects of pharmaceuticals on the nitrification}

To explain the impact of pharmaceuticals on nitrification, several examples can be reviewed (Table 1). The inhibitory effect of drugs on nitrifying microorganisms, in addition to being important for treatment plant efficiency, is relevant as a signal of potential negative effects on aquatic organisms when pharmaceutical-containing wastewater is discharged to a receiving water body (Carucci et al., 2006). In addition, at $250 \mathrm{mg} / \mathrm{L}$ concentrations, acetaminophen had a significant inhibitory effect $(>25 \%)$ on nitrification and denitrification rates (Barra Caracciolo et al., 2015). On the other hand, the nitrification process is an important part of the removal process of pharmaceuticals. Various mechanisms are used to remove pharmaceuticals from water including photodegradation, sorption, biodegradation, and phytoremediation (Hijosa-Valsero et al., 2016). According to some studies, pharmaceuticals can be removed through the nitrification process (autotrophic biodegradation) (Peng et al., 2019). Indeed, it is known that nitrification can enhance pharmaceuticals removal (He et al., 2018). For example, there was high removal of diclofenac, ibuprofen, paracetamol, and metoprolol (60-100\%) and partial removal of trimethoprim and carbamazepine (30 and 60\%) (Köpping et al., 2020). Many studies also found that some pharmaceuticals had no effects on nitrification, such as tetracycline on nitrification (He et al., 2021).

\section{Ammonification}

Ammonification is defined as any chemical reaction that converts $\mathrm{NH}_{2}$ groups into ammonia or its ionic form, ammonium $\left(\mathrm{NH}_{4}^{+}\right)$, as an end product, and it is the final step of the nitrogen cycle that involves an 
Table 1 List of observed effects of pharmaceuticals on the nitrification rate

\begin{tabular}{|c|c|c|c|c|c|}
\hline Compound/ Drug Class & Molecular Formula & Chemical Structure & Concentration & Effect/Sample type & Reference \\
\hline $\begin{array}{l}\text { Acetaminophen } \\
\text { (Analgesic) }\end{array}$ & $\mathrm{C}_{8} \mathrm{H}_{9} \mathrm{NO}_{2}$ & & $250 \mathrm{mg} \cdot \mathrm{L}^{-1}$ & $\begin{array}{c}\text { Inhibition } \\
\text { (Water sample) }\end{array}$ & $\begin{array}{c}\text { (Barra Caracciolo } \\
\text { et al., 2015) }\end{array}$ \\
\hline $\begin{array}{c}\text { Erythromycin } \\
\text { (Macrolide antibiotic) }\end{array}$ & $\mathrm{C}_{37} \mathrm{H}_{67} \mathrm{NO}_{13}$ & & $20 \mathrm{mg} \cdot \mathrm{L}^{-1}$ & $\begin{array}{c}\text { Inhibition } \\
\text { (Water sample) }\end{array}$ & $\begin{array}{l}\text { (Alighardashi et } \\
\text { al., 2009) }\end{array}$ \\
\hline $\begin{array}{l}\text { Tetracycline } \\
\text { (Antibiotic) }\end{array}$ & $\mathrm{C}_{22} \mathrm{H}_{24} \mathrm{~N}_{2} \mathrm{O}_{8}$ & & $200 \mathrm{mg} \cdot \mathrm{L}^{-1}$ & $\begin{array}{c}\text { Inhibition } \\
\text { (Water sample) }\end{array}$ & $\begin{array}{c}\text { (Katipoglu-Yazan } \\
\text { et al., 2013) }\end{array}$ \\
\hline $\begin{array}{l}\text { Norfloxacin } \\
\text { (Antibiotic) }\end{array}$ & $\mathrm{C}_{16} \mathrm{H}_{18} \mathrm{FN}_{3} \mathrm{O}_{3}$ & & $1 \mathrm{mg} \cdot \mathrm{kg}^{-1}$ & $\begin{array}{c}\text { Stimulation } \\
\text { (Soil sample) }\end{array}$ & $\begin{array}{l}\text { (Yang et al., } \\
\text { 2012) }\end{array}$ \\
\hline $\begin{array}{l}\text { Sulfadiazine } \\
\text { (Antibiotic) }\end{array}$ & $\mathrm{C}_{10} \mathrm{H}_{10} \mathrm{~N}_{4} \mathrm{O}_{2} \mathrm{~S}$ & & $100 \mathrm{mg} \cdot \mathrm{kg}^{-1}$ & $\begin{array}{c}\text { Inhibition } \\
\text { (Soil sample) }\end{array}$ & $\begin{array}{l}\text { (Kotzerke et al., } \\
\text { 2008) }\end{array}$ \\
\hline $\begin{array}{c}\text { Sulfadimethoxine } \\
\text { (Sulfonamide) }\end{array}$ & $\mathrm{C}_{12} \mathrm{H}_{14} \mathrm{~N}_{4} \mathrm{O}_{4} \mathrm{~S}$ & & $50 \mathrm{mg} \cdot \mathrm{kg}^{-1}$ & $\begin{array}{c}\text { Inhibition } \\
\text { (Soil sample) }\end{array}$ & (Toth et al., 2011) \\
\hline $\begin{array}{c}\text { Triclosan } \\
\text { (Anti-infective agents) }\end{array}$ & $\mathrm{C}_{12} \mathrm{H}_{7} \mathrm{Cl}_{3} \mathrm{O}_{2}$ & & $89.1 \mu \mathrm{g} . \mathrm{L}^{-1}$ & $\begin{array}{c}\text { Inhibition } \\
\text { (Water sample) }\end{array}$ & $\begin{array}{l}\text { (Lopez et al., } \\
\text { 2021) }\end{array}$ \\
\hline $\begin{array}{c}\text { Ciprofloxacin } \\
\text { (Fluoroquinolone) }\end{array}$ & $\mathrm{C}_{17} \mathrm{H}_{18} \mathrm{FN}_{3} \mathrm{O}_{3}$ & & $1 \mathrm{mg} \cdot \mathrm{kg}^{-1}$ & $\begin{array}{l}\text { Stimulation } \\
\text { (Soil sample) }\end{array}$ & (Cui et al., 2014) \\
\hline $\begin{array}{l}\text { Oxytetracycline } \\
\text { (Antibiotic) }\end{array}$ & $\mathrm{C}_{22} \mathrm{H}_{24} \mathrm{~N}_{2} \mathrm{O}_{9}$ & & $\begin{array}{l}50 \mathrm{mg} \cdot \mathrm{L}^{-1} \\
75 \mathrm{mg} \cdot \mathrm{L}^{-1}\end{array}$ & $\begin{array}{c}\text { Inhibition } \\
\text { (Water sample) }\end{array}$ & $\begin{array}{c}\text { (Klaver \& } \\
\text { Matthews., 1994) }\end{array}$ \\
\hline
\end{tabular}


organic compound and serves as a link between the depolymerization of large organic molecules and the nitrification step. In other words, the production of ammonium from organic matter is known as mineralization, which is sometimes referred to as ammonification (Kendall et al., 2013). Mineralization is known to be important in marine and terrestrial environments. Mineralization of bacteria and phytoplankton in sea water column can be an important source of nutrients in the water (Kendall et al., 2013).

\section{Ammonification in water}

The intensity of bacterial ammonification in water bodies is proportional to the amount of organic matter present (Billen \& Fontigny, 1987; Podgórska \& Mudryk, 2007). Because biological ammonium assimilation by bacteria, biofilms, and aquatic plants is preferable to nitrate assimilation, ammonification of organic nitrogen is an important process in water. When a plant or animal dies or an animal expels waste, the initial form of nitrogen is organic. Bacteria or fungi convert organic nitrogen from organic substrates back to ammonium $\left(\mathrm{NH}_{4}^{+}\right)$, in a process called ammunition or mineralization. The enzymes involved are as follows: glutamine synthetase (cytosolic and plastic); glutamine 2-oxoglutarate aminotransferase (Ferredoxin and NADH-dependent), and glutamine dehydrogenase, which have a minor role in the assimilation of ammonium, but are important in the catabolism of amino acids (Butnariu \& Butu, 2019a). In this first stage of ammonification, nitrogenous organic residues are transformed into ammonia derivatives. This is done by bacteria such as Bacillus, Bacterium, or Micrococcus. In water, ammonia derivatives exist in two chemical forms (Butnariu \& Butu, 2019b). The first is free molecular ammonia $\left(\mathrm{NH}_{3}\right)$, a rarefied gas that is formed especially if the $\mathrm{pH}$ of the water is greater than or equal to 7. At a pH of less than 7, ammonia associates with a water molecule and forms ammonium hydroxide $\left(\mathrm{NH}_{4} \mathrm{OH}\right)$ (Vardanian et al., 2018). Ammonification starts right from the moment we introduce water into the aquarium because this environment is never $100 \%$ pure. The concentration of ammonia derivatives then increases progressively. Now, these derivatives are broken down by bacteria, present in large numbers. A recent study found that after 11 days, the ammonia concentration was already close to zero (Butu et al., 2020).
Ammonification in soil

Nitrogenous organic substances, which account for 99\% of total $\mathrm{N}$ reserves of most soils (ButterbachBahl et al., 2011), are made up of humic reserves and other compounds that naturally accumulate in the soil as a result of the biological fixation of $\mathrm{N}_{2}$ and the degradation of plant and animal organic residues and manure. The bacterial cells themselves represent a mass of organic substance, predominantly protein, of about 6 tons/ha, to which are added about 20 tons represented by the rest of the microflora and microfauna. Microflora refers to the smallest organisms, such as bacteria, actinomycetes, fungi, and algae, while soil animals range in size from microscopic (microfauna) to mites, earthworms, and small mammals (mesofauna and macrofauna) (Gentry \& Zuberer, 2021). If this organic $\mathrm{N}$ remained unchanged, the $\mathrm{N}$ reserves available to plants would diminish year after year, eventually ceasing to allow plant growth. Normally, however, these substances undergo a mineralization process, at the end of which they are brought to the state of $\mathrm{NH}_{3}$ (Jarvis et al., 2011). The ammonification process itself is preceded by the decomposition of protein molecules by hydrolysis, using extracellular proteases released by numerous species of aerobic and anaerobic microorganisms according to the general formula:

Protein $\rightarrow$ peptone peptides $\rightarrow$ amino acid under the influence of enzymes: proteinase, peptonase, peptidase, and with the elimination of water.

The amino acids resulting from this degradation enter the bacterial cells, where they undergo a deamination process, which results in $\mathrm{NH}_{3}$ and the corresponding organic acid (Park et al., 2014). There are several types of deamination, namely (1) hydrolytic deamination, (2) hydrolytic and decarboxylation deamination, (3) reducing deamination, (4) reducing decarboxylation deamination (anaerobic), (5) oxidative deamination with decarboxylation, and (6) desaturation with desaturation.

Such reactions, in addition to $\mathrm{N}$ mineralization, result in organic acid formations: acetic, formic, propionic, butyric, valerian. Depending on the environmental conditions and the nature of the microflora, these acids can be completely oxidized to $\mathrm{CO}_{2}$ and $\mathrm{H}_{2} \mathrm{O}$ (in the aerobic environment), accumulated as such, transformed into alcohols. Ammonification in the strict sense can therefore be defined as a 
biological process in which $\mathrm{NH}_{3}$ is released into the soil, as a result of the action of soil microflora on amino acids resulting from the decomposition of protein substances (Butterbach-Bahl et al., 2011). In this sense, the release of $\mathrm{NH}_{3}$ under the action of temporary root mycoflora is not included in the ammonification. In this process, $\mathrm{NH}_{3}$ can be reused as such by a whole range of microorganisms. Most of it still undergoes a transformation absolutely necessary for life in the soil, in forms accessible to plants, and the rest can be fixed in the soil, especially in acid soils or evaporate into the atmosphere. The microflora capable of producing ammonification of protein substances is numerous and diverse, and it acts as follows over time: aerobic bacteria enter the picture early on in the process, such as Bacillus cereus var. mycoides, B. subtilis, B. thermoproteolyticus (Elshaghabee et al., 2017), unsporulated species such as Serratia marcescens and Arthrobacter, and facultatively anaerobic species such as Proteus vulgaris, Pseudomonas fluorescens, Escherichia coli, and Sarcina lutea (Stieglmeier et al., 2009). After 2-3 days, anaerobic species such as Clostridium putrefaciens, C. perfringens (EFSA, 2005), and some actinomycetes such as Streptomyces violaceus and Micromonospora chalcea (Bredholdt et al., 2007) come into action, which begin to predominate and make the release of $\mathrm{NH}_{3}$ to be maximum. Moulds invade the environment, and the release of $\mathrm{NH}_{3}$ decreases because they use $\mathrm{NH}_{3}$ for protein synthesis and produce a lot of acids that neutralize the ammonia. Urea hydrolysis is performed by a large group of microorganisms capable of producing the enzyme urease (Mekonnen et al., 2021). In this group, we find species of the genera: Achromobacter sp., Bacillus sp., Clostridium sp., Corynebacterium sp., Pseudomonas sp., Actinomycetes, and filamentous microfungi. To these is added the urobacteria group, which is distinguished by resistance to high concentrations of urea and alkaline $\mathrm{pH}$, as well as the ability to release large amounts of $\mathrm{NH}_{3}$. Urobacteria include Bacillus (Urobacillus) pastures, Micrococcus ureae, Planosarcina ureae, and others. The ammonifying activity of urobacteria is very important because urea contains $47 \% \mathrm{~N}_{2}$ - which would otherwise be unused by plants.

Effects of pharmaceuticals on the ammonification

The nitrification process is more sensitive to different chemicals such as pharmaceuticals than the ammonification process partly because of the diversity of organisms associated with ammonification (Cycon et al., 2016). Various pharmaceuticals have a negative impact for instance, Cycon et al., (2016) reported that stimulation happened in $1 \mathrm{mg} \cdot \mathrm{kg}^{-1}$ soil of naproxen and ketoprofen after 1, 15, and 30 days, while diclofenac and ibuprofen had no effect on the rate of ammonification (Table 2). Moreover, in a concentration of $100 \mathrm{mg} \mathrm{kg}^{-1}$, the complex of pharmasin and nystatin had the greatest inhibitory effect on

Table 2 List of observed effects of pharmaceuticals on the ammonification rate

\begin{tabular}{|c|c|c|c|c|c|}
\hline Compound/ Drug Class & Molecular Formula & Chemical Structure & Concentration & Effect/Sample type & Reference \\
\hline $\begin{array}{c}\text { Erythromycin } \\
\text { (Macrolide antibiotic) }\end{array}$ & $\mathrm{C}_{37} \mathrm{H}_{67} \mathrm{NO}_{13}$ & & $20 \mathrm{mg} \cdot \mathrm{L}^{-1}$ & $\begin{array}{c}\text { Inhibition } \\
\text { (Water sample) }\end{array}$ & $\begin{array}{c}\text { (Alighardashi et } \\
\text { al., 2009) }\end{array}$ \\
\hline $\begin{array}{l}\text { Naproxen } \\
\text { (Analgesic) }\end{array}$ & $\mathrm{C}_{14} \mathrm{H}_{14} \mathrm{O}_{3}$ & & $1 \mathrm{mg} \cdot \mathrm{kg}^{-1}$ & $\begin{array}{c}\text { Stimulation } \\
\text { (Soil sample) }\end{array}$ & $\begin{array}{l}\text { (Cycon et al., } \\
\text { 2016) }\end{array}$ \\
\hline $\begin{array}{c}\text { Ketoprofen } \\
\text { (Nonsteroidal anti- } \\
\text { inflammatory drugs) }\end{array}$ & $\mathrm{C}_{16} \mathrm{H}_{14} \mathrm{O}_{3}$ & & $1 \mathrm{mg} \cdot \mathrm{kg}^{-1}$ & $\begin{array}{l}\text { Stimulation } \\
\text { (Soil sample) }\end{array}$ & $\begin{array}{c}\text { (Cycon et al., } \\
\text { 2016) }\end{array}$ \\
\hline
\end{tabular}


ammonifiers, while the complex of benzylpenicillin and nystatin had the least (Akimenko et al., 2015). On the other hand, at concentrations higher than $20 \mathrm{mg}$ $\mathrm{L}^{-1}$, erythromycin significantly inhibits ammonia formation in water (Alighardashi et al., 2009). However, data on the effects of pharmaceuticals on ammonification and anammox is lacking, and more research is needed in the future.

\section{Denitrification}

Denitrification is the microbial process of converting nitrate and nitrite to gaseous nitrogen forms, primarily nitrous oxide $\left(\mathrm{N}_{2} \mathrm{O}\right)$ and nitrogen $\left(\mathrm{N}_{2}\right)$. The availability of $\mathrm{N}$ oxides, nitrite $\left(\mathrm{NO}_{2}^{-}\right)$, or nitrate $\left(\mathrm{NO}_{3}{ }^{-}\right)$is formed from the autotrophic nitrification pathway substrate; ammonia $\left(\mathrm{NH}_{3}\right)$, which is derived from ammonium $\left(\mathrm{NH}_{4}^{+}\right)$, is the key to denitrification as defined (Martens, 2004). The nitrate ion acts as a terminal electron acceptor in the absence of oxygen during the process of respiration, leading to a sequence of reduction reactions which ultimately produce $\mathrm{N}_{2}$ :

$\mathrm{NO}_{3}^{-} \rightarrow \mathrm{NO}_{2}^{-} \rightarrow \mathrm{NO} \rightarrow \mathrm{N}_{2} \mathrm{O} \rightarrow \mathrm{N}_{2}$

Denitrification is a process that occurs in all of our terrestrial and aquatic ecosystems, including tropical and temperate soils, natural and intensively managed ecosystems, marine and freshwater environments, wastewater treatment plants, manure storage facilities, and aquifers. The factors that determine the rate of denitrification are nitrate availability, the availability of an oxidizable organic substrate, and the oxygen concentration (indirectly determined by soil water content) (Butterbach-Bahl et al., 2011).

\section{Denitrification in water}

An increase in nitrate concentrations in groundwater observed worldwide as a result of fertilizer use and industrial wastewater raises concerns due to the serious consequences for human health (Park et al., 2005). One of the most important applications of denitrification is in water treatment. For many years, denitrification has been utilized for treatment in aquatic environments especially for wastewater (Gayle et al., 1989). Moreover, nitrification and denitrification are the two most common items for removing inorganic nitrogen from wastewater (Zhu et al., 2016).

\section{Denitrification in soil}

Nitrates accumulated in the soil, as a result of the nitrification process or by application of fertilizers, are partly consumed by higher plants, and a variable amount is washed away by infiltration and runoff. Microorganisms can use nitrates in two ways: they can be assimilated during protoplasm synthesis (assimilation of nitrites), or they can be reduced to oxidize an organic or mineral substance (Butnariu \& Buţu, 2020). Denitrification is a process that closes the circuit by returning molecular $\mathrm{N}_{2}$ to nature. The reduction of nitrates in the denitrification process creates either $\mathrm{N}_{2}$ or $\mathrm{NH}_{3}$ and releases intermediate compounds such as the greenhouse gas $\mathrm{N}_{2} \mathrm{O}$. Optimal production conditions are achieved in water-saturated soils and in deep structures in which the following groups of microorganisms can react (Butu et al., 2021). The actual denitrifying bacteria that reduce $\mathrm{NO}_{3}{ }^{-}$to $\mathrm{N}_{2}$ are Pseudomonas stutzeri and Pseudomonas denitrificans. Bacillus megaterium, Escherichia coli, Pseudomonas aeruginosa, and other microorganisms in the general soil flora are capable of reducing $\mathrm{NO}_{3}{ }^{-}$to $\mathrm{NO}_{2}^{-}$, as are some sulfurous bacteria such as Thiobacillus denitrificans. It is certain that the reduction of nitrates to gaseous $\mathrm{N}_{2}$ represents for the soil a real loss that can reach up to $120 \mathrm{~kg} \mathrm{~N}_{2} / \mathrm{ha} /$ year, although some of the released $\mathrm{N}_{2}$ can be taken up by anaerobic $\mathrm{N}_{2}$ fixatives such as Clostridium pasteurianum (Bagiu et al., 2020a). It also is of environmental concern given that $\mathrm{N}_{2} \mathrm{O}$ is a greenhouse gas with nearly 300 times the warming potential of $\mathrm{CO}_{2}$. At the same time, incomplete reduction, up to the intermediate stages, of nitrites and $\mathrm{NH}_{3}$ is less detrimental to the soil fertility, as $\mathrm{NH}_{3}$ can be used by some heterotrophic microorganisms, while nitrites are taken up by nitrate bacteria and nitrate reoxidations (Bagiu et al., 2020b).

Effects of pharmaceuticals on the denitrification

The conversion of nitrates to gaseous nitrogen occurs in the production of alkalinity, leading to an increase of $\mathrm{pH}$. The optimum values of $\mathrm{pH}$ are in $7-8$ domains with different optimal values for different bacterial populations (Simek et al., 2002). In case that for the 
denitrification process is not enough organic substrate for his ensuring it can be used different organic compounds as: methanol, ethanol, acetic acid, residues of organic materials. Most used sources as electron donors are the organic matter from wastewater and methanol. Their choosing is made having regarded the economic part and the local availability. Table 3 combines several types of research that examined how pharmaceuticals affect denitrification in water and soil.

The widespread nature of denitrification in soils reflects the underlying diversity of soil microorganisms that are responsible (Butterbach-Bahl et al., 2013). This diversity of organisms is likely to mean that individual pharmaceutical products are unlikely to completely inhibit the denitrification process since in cases where inhibition of individual species or genera occurs as there are usually other species that can take over the denitrifying role. For this reason, the denitrification process appears to be less sensitive to the presence of pharmaceutical substrates than other $\mathrm{N}$ cycle processes.

\section{Anammox}

The anammox process accounts for a significant portion of nitrogen conversion in the oceans (Chen et al., 2019). There appear to be some enzymatic similarities between anammox and aerobic $\mathrm{NH}_{3}$ oxidation,

Table 3 List of observed effects of pharmaceuticals on the denitrification rate

\begin{tabular}{|c|c|c|c|c|c|}
\hline Compound/ Drug Class & Molecular Formula & Chemical Structure & Concentration & Effect/Sample type & Reference \\
\hline $\begin{array}{c}\text { Acetaminophen } \\
\text { (Analgesic) }\end{array}$ & $\mathrm{C}_{8} \mathrm{H}_{9} \mathrm{NO}_{2}$ & & $250 \mathrm{mg} \cdot \mathrm{L}^{-1}$ & $\begin{array}{c}\text { Inhibition } \\
\text { (Water sample) }\end{array}$ & $\begin{array}{c}\text { (Barra Caracciolo } \\
\text { et al., 2015) }\end{array}$ \\
\hline $\begin{array}{c}\text { Sulfamethoxazole } \\
\text { (Antibiotic) }\end{array}$ & $\mathrm{C}_{10} \mathrm{H}_{11} \mathrm{~N}_{3} \mathrm{O}_{3} \mathrm{~S}$ & & $\begin{array}{l}0.99 \mu \mathrm{M} \\
505 \mu \mathrm{M}\end{array}$ & $\begin{array}{c}\text { Inhibition } \\
\text { (Water sample) }\end{array}$ & $\begin{array}{l}\text { (Underwood et } \\
\text { al., 2011) }\end{array}$ \\
\hline $\begin{array}{l}\text { Sulfamethazine } \\
\text { (Antibacterial) }\end{array}$ & $\mathrm{C}_{12} \mathrm{H}_{14} \mathrm{~N}_{4} \mathrm{O}_{2} \mathrm{~S}$ & & $0.01 \mathrm{mg} \cdot \mathrm{L}^{-1}$ & $\begin{array}{c}\text { Inhibition } \\
\text { (Water sample) }\end{array}$ & $\begin{array}{c}\text { (Ahmad et al., } \\
\text { 2014) }\end{array}$ \\
\hline $\begin{array}{l}\text { Chlortetracycline } \\
\text { (Tetracyclines) }\end{array}$ & $\mathrm{C}_{22} \mathrm{H}_{23} \mathrm{ClN}_{2} \mathrm{O}_{8}$ & & $1.0 \mathrm{mg} \cdot \mathrm{L}^{-1}$ & $\begin{array}{c}\text { Inhibition } \\
\text { (Water sample) }\end{array}$ & $\begin{array}{c}\text { (Ahmad et al., } \\
\text { 2014) }\end{array}$ \\
\hline $\begin{array}{c}\text { Narasin } \\
\text { (anticoccidial) }\end{array}$ & $\mathrm{C}_{43} \mathrm{H}_{72} \mathrm{O}_{11}$ & & $500 \mu \mathrm{g} \cdot \mathrm{kg}^{-1}$ & $\begin{array}{c}\text { Inhibition } \\
\text { (Soil sample) }\end{array}$ & $\begin{array}{c}\text { (DeVries et al., } \\
\text { 2015) }\end{array}$ \\
\hline $\begin{array}{l}\text { Sulfamethazine } \\
\text { (Antibacterial) }\end{array}$ & $\mathrm{C}_{12} \mathrm{H}_{14} \mathrm{~N}_{4} \mathrm{O}_{2} \mathrm{~S}$ & & $5 \mu \mathrm{g} \cdot \mathrm{L}^{-1}$ & $\begin{array}{c}\text { Inhibition } \\
\text { (Water sample) }\end{array}$ & (Hou et al., 2015) \\
\hline
\end{tabular}


and anammox has the same ecological significance as denitrification, i.e. the loss of fixed nitrogen in anoxic environments (Ward, 2008). Anammox (anaerobic ammonium oxidation), a reaction that oxidizes ammonium to dinitrogen gas under anoxic conditions using nitrite as the electron acceptor, was a significant discovery in the nitrogen cycle. Nitrite and ammonium are converted into dinitrogen gas in this process:

$\mathrm{NH}_{4}^{+}+\mathrm{NO}_{2}^{-} \rightarrow \mathrm{N}_{2}+2 \mathrm{H}_{2} \mathrm{O}$

Anammox in water

Anaerobic ammonium-oxidizing (anammox) bacteria are one of the most recent additions to the biogeochemical nitrogen cycle and can produce more than half of the $\mathrm{N}_{2}$ gas released (Jetten et al., 2009). There are five types of anammox bacteria: (1) Ca. Brocadia, (2) Ca. Jettenia, (3) Ca. Kuenenia, (4) Ca. Anammoxoglobus, and (5) Ca. Scalindua (Kartal et al., 2007, 2008; Kuypers et al., 2005; Quan et al., 2008; Schmid et al., 2000, 2003; Strous et al., 1999; $\mathrm{Wu}$ et al., 2019). Anammox bacteria exist in a variety of natural habitats, including anoxic marine sediments and water columns, freshwater sediments, water columns, freshwater marshes, rivers, meromictic lakes, and river estuaries (Dale et al., 2009; Humbert et al., 2010; Kuypers et al., 2005; Lam et al., 2009; Long et al., 2013; Philippot et al., 2007; Rich et al., 2008; Schmid et al., 2007; Schubert et al., 2006; Thamdrup et al., 2006; Trimmer et al., 2003; Zhang et al., 2007).

Table 4 List of observed effects of pharmaceuticals on the anammox rate

\begin{tabular}{|c|c|c|c|c|c|}
\hline Compound/ Drug Class & Molecular Formula & Chemical Structure & Concentration & Effect & Reference \\
\hline $\begin{array}{l}\text { Tetracycline hydrochloride } \\
\text { (Antibiotic) }\end{array}$ & $\mathrm{C}_{22} \mathrm{H}_{25} \mathrm{ClN}_{2} \mathrm{O}_{8}$ & & $100 \mathrm{mg} \cdot \mathrm{L}^{-1}$ & $\begin{array}{c}\text { Inhibition } \\
\text { (Water sample) }\end{array}$ & $\begin{array}{l}\text { (Fernández et al., } \\
\text { 2009) }\end{array}$ \\
\hline $\begin{array}{l}\text { Oxytetracycline } \\
\text { (Antibiotic) }\end{array}$ & $\mathrm{C}_{22} \mathrm{H}_{24} \mathrm{~N}_{2} \mathrm{O}_{9}$ & & $200 \mathrm{mg} \cdot \mathrm{L}^{-1}$ & $\begin{array}{c}\text { Inhibition } \\
\text { (Water sample) }\end{array}$ & (Lotti et al., 2012) \\
\hline $\begin{array}{l}\text { Sulfathiazole } \\
\text { (Antibiotic) }\end{array}$ & $\mathrm{C}_{9} \mathrm{H}_{9} \mathrm{~N}_{3} \mathrm{O}_{2} \mathrm{~S}_{2}$ & & $100 \mathrm{mg} \cdot \mathrm{L}^{-1}$ & $\begin{array}{c}\text { Inhibition } \\
\text { (Water sample) }\end{array}$ & (Lotti et al., 2012) \\
\hline $\begin{array}{l}\text { Chloramphenicol } \\
\text { (Antibiotic) }\end{array}$ & $\mathrm{C}_{11} \mathrm{H}_{12} \mathrm{Cl}_{2} \mathrm{~N}_{2} \mathrm{O}_{5}$ & & $250 \mathrm{mg} \cdot \mathrm{L}^{-1}$ & $\begin{array}{c}\text { Inhibition } \\
\text { (Water sample) }\end{array}$ & $\begin{array}{l}\text { (Fernández et al., } \\
\text { 2009) }\end{array}$ \\
\hline $\begin{array}{l}\text { Oxytetracycline } \\
\text { (Antibiotic) }\end{array}$ & $\mathrm{C}_{22} \mathrm{H}_{24} \mathrm{~N}_{2} \mathrm{O}_{9}$ & & $250 \mathrm{mg} \cdot \mathrm{L}^{-1}$ & $\begin{array}{c}\text { Inhibition } \\
\text { (Water sample) }\end{array}$ & $\begin{array}{l}\text { (Tang et al., } \\
\text { 2011) }\end{array}$ \\
\hline $\begin{array}{c}\text { Doxycycline } \\
\text { (Anti-infective agents) }\end{array}$ & $\mathrm{C}_{22} \mathrm{H}_{26} \mathrm{~N}_{2} \mathrm{O}_{9}$ & & $50 \mathrm{mg} \cdot \mathrm{L}^{-1}$ & $\begin{array}{c}\text { Inhibition } \\
\text { (Water sample) }\end{array}$ & $\begin{array}{l}\text { (Sguanci et al., } \\
\text { 2017) }\end{array}$ \\
\hline $\begin{array}{l}\text { Enrofloxacin } \\
\text { (Antibiotic) }\end{array}$ & $\mathrm{C}_{19} \mathrm{H}_{22} \mathrm{FN}_{3} \mathrm{O}_{3}$ & & $50 \mathrm{mg} \cdot \mathrm{L}^{-1}$ & $\begin{array}{c}\text { Inhibition } \\
\text { (Water sample) }\end{array}$ & $\begin{array}{l}\text { (Sguanci et al., } \\
\text { 2017) }\end{array}$ \\
\hline
\end{tabular}


Indeed, the anammox process offers an appealing alternative to current wastewater treatment systems for ammonia-nitrogen removal (Jetten et al., 2009). Moreover, anammox research has primarily focused on its role in the oceanic nitrogen cycle, with anammox contributing more than $50 \%$ of $\mathrm{N}_{2}$ loss in some marine environments (Arrigo, 2005; Devol, 2015; Xi et al., 2016).

\section{Anammox in soil}

Anammox bacteria have also been detected in permafrost soils, reductisol, agricultural soils, peat soils, and rice paddy soils (Humbert et al., 2010; Long et al., 2013; Philippot et al., 2007; Zhu et al., 2011), and anammox bacteria were detected to be more common and phylogenetically diverse in terrestrial ecosystems than in most other environments (Humbert et al., 2010, 2012; Moore et al., 2011; Zhu et al., 2011). For instance, anammox activity accounts for 1 to $37 \%$ of total $\mathrm{N}_{2}$ loss from paddy soils (Sato et al., 2012; Xi et al., 2016; Zhu et al., 2011).

\section{Effects of pharmaceuticals on the anammox}

Several studies have found that pharmaceuticals have a negative effect on anammox bacteria (Table 4). Environmental factors such as temperature, heavy metals, nanomaterials, and antibiotics limit the growth of anammox bacteria (Li et al., 2019; Zhang et al., 2019b, 2021).

\section{Conclusions}

This review has demonstrated that pharmaceuticals can exert a wide range of stimulatory and inhibitory effects on nitrogen cycle processes in different environments, which may be modified by different concentrations and types of pharmaceuticals. Even at low concentrations, nitrification and denitrification appear sensitive to pharmaceuticals $\left(\mu \mathrm{g} \cdot \mathrm{L}^{-1}\right)$. However, inadequate information exists regarding how pharmaceuticals can affect nitrogen fixation and ammonification or how they interact in the environment. It is likely that a range of mechanisms is responsible for the observed impacts of pharmaceutical products including direct stimulation or inhibition of microbial populations, alterations of rates of chemical reactions (through impacts on enzyme controlled metabolic pathways), indirect actions (such as reactions with substrates influencing to microbial activity, and other indirect impacts of pharmaceutical products. Such information is critically important if we are to develop more sustainable use of nitrogen as a critical component of our food production systems. Future investigations will need to take a more systematic and comprehensive approach to address these concerns. We need to know more about the source, the pathways of transport, and longevity of pharmaceuticals in the environment to fully understand their impact. The process of decomposition of biologically active molecules can also lead to the production of intermediate products that can have impacts on the environment. There is evidence that the effects of pharmaceutical exposure may not manifest themselves for as long as 1 year after initial exposure, underscoring the need for long-term studies that replicate pharmaceutical applications over time or deliver continuous exposure (DeVries \& Zhang, 2016). Thus, future investigations will need to take a more systematic and comprehensive approach to address these concerns.

Acknowledgements This research was supported by the Doctorate Study Programme in Ecology and Environmental Sciences, Marine Research Institute of Klaipeda University, and Nicolaus Copernicus University in Torun. The authors gratefully acknowledge Prof. Monica Butnariu for editing this article.

\section{Declarations}

Consent for Publication We confirm that all authors have read the manuscript and agree to its submission in Environmental Monitoring and Assessment.

Conflict of Interest The authors declare no competing interests.

\section{References}

Abu Shmeis, R. M. (2018). Water chemistry and microbiology. In Comprehensive analytical chemistry (1st ed., Vol. 81). Elsevier B.V. https://doi.org/10.1016/bs.coac.2018.02.001

Ahmad, M., Vithanage, M., Kim, K., Cho, J. S., Lee, Y. H., Joo, Y. K., Lee, S. S., \& Ok, Y. S. (2014). Inhibitory effect of veterinary antibiotics on denitrification in groundwater: A microcosm approach. The Scientific World Journal, 2014. https://doi.org/10.1155/2014/879831

Akimenko, Y. V., Kazeev, K. S., \& Kolesnikov, S. I. (2015). Impact assessment of soil contamination with antibiotics (for example, an ordinary chernozem). American Journal 
of Applied Sciences, 12(2), 80-88. https://doi.org/10. 3844/ajassp.2015.80.88

Alighardashi, A., Pandolfi, D., Potier, O., \& Pons, M. N. (2009). Acute sensitivity of activated sludge bacteria to erythromycin. Journal of Hazardous Materials, 172(2-3), 685692. https://doi.org/10.1016/j.jhazmat.2009.07.051

Arrigo, K. R. (2005). Marine microorganisms and global nutrient cycles. Nature, 437(7057), 349-355. https://doi.org/ 10.1038/nature04159

Baggs, E. M., Smales, C. L., \& Bateman, E. J. (2010). Changing $\mathrm{pH}$ shifts the microbial source as well as the magnitude of $\mathrm{N} 2 \mathrm{O}$ emission from soil. Biology and Fertility of Soils, 46(8), 793-805. https://doi.org/10.1007/ s00374-010-0484-6

Bagiu, R. V., Sarac, I., Radu, F., Cristina, R. T., Butnariu, M., \& Bagiu, I. C. (2020a). Chemical transformations of synthetic persistent substances. In: R. Bhat, K. Hakeem, N. Saud Al-Saud (Eds.), Bioremediation and biotechnology, Vol 3. Springer, Cham. https://doi.org/10.1007/ 978-3-030-46075-4_5

Bagiu, I. C., Sarac, I., Radu, F., Bostan, C., Butnariu, M., \& Bagiu, R. V. (2020b). Ecotechnologies for persistent pollutants. In: R. Bhat, K. Hakeem, N. Saud Al-Saud (Eds.), Bioremediation and biotechnology, Vol 3. Springer, Cham. https://doi. org/10.1007/978-3-030-46075-4_6

Barra Caracciolo, A., Topp, E., \& Grenni, P. (2015). Pharmaceuticals in the environment: Biodegradation and effects on natural microbial communities. A review. Journal of Pharmaceutical and Biomedical Analysis, 106, 25-36. https://doi.org/10.1016/j.jpba.2014.11.040

Beeckman, F., Motte, H., \& Beeckman, T. (2018). Nitrification in agricultural soils: Impact, actors and mitigation. Current Opinion in Biotechnology, 50, 166-173. https://doi. org/10.1016/j.copbio.2018.01.014

Behar, A., Yuval, B., \& Jurkevitch, E. (2005). Enterobacteriamediated nitrogen fixation in natural populations of the fruit fly Ceratitis capitata. Molecular Ecology, 14(9), 2637-2643. https://doi.org/10.1111/j.1365-294X.2005. 02615.x

Berges, J. A., \& Mulholland, M. R. (2008). Enzymes and nitrogen cycling. In Nitrogen in the Marine Environment (issue October). https://doi.org/10.1016/B978-0-12-372522-6.00032-3

Billen, G., \& Fontigny, A. (1987). Dynamics of a Phaeocystisdominated spring bloom in Belgian coastal waters. II. Bacterioplankton Dynamics. Marine Ecology Progress Series, 37, 249-257. https://doi.org/10.3354/meps037249

Boxall, A. B. A. (2004). The environmental side effects of medication: How are human and veterinary medicines in soils and water bodies affecting human and environmental health? EMBO Reports, 5(12), 1110-1116. https:// www.ncbi.nlm.nih.gov/pmc/articles/PMC1299201/

Brandt, K. K., Amézquita, A., Backhaus, T., Boxall, A., Coors, A., Heberer, T., Lawrence, J. R., Lazorchak, J., Schönfeld, J., Snape, J. R., Zhu, Y. G., \& Topp, E. (2015). Ecotoxicological assessment of antibiotics: A call for improved consideration of microorganisms. Environment International, 85, 189-205. https://doi. org/10.1016/j.envint.2015.09.013

Bredholdt, H., Galatenko, O. A., Engelhardt, K., Fjærvik, E., Terekhova, L. P., \& Zotchev, S. B. (2007). Rare actinomycete bacteria from the shallow water sediments of the Trondheim fjord, Norway: Isolation, diversity and biological activity. Environmental Microbiology, 9(11), 2756-2764. https://doi.org/10.1111/j.1462-2920.2007. 01387.x

Butnariu, M., \& Butu, A. (2019a) Microbial nanobionics: Application of nanobiosensors in microbial growth and diagnostics. In: R. Prasad (Ed.), Microbial nanobionics. Nanotechnology in the Life Sciences. Springer, Cham. https://doi. org/10.1007/978-3-030-16383-9_9

Butnariu, M., \& Butu, A. (2019b). Plant nanobionics: Application of nanobiosensors in plant biology. In Nanotechnology in the Life Sciences. https://doi.org/10.1007/ 978-3-030-16379-2_12

Butnariu, M., \& Buţu, M. (2020). Bioremediation: A viable approach for degradation of petroleum hydrocarbon. Springer. https://doi.org/10.1007/978-3-030-48690-7_9

Butterbach-Bahl, K., Baggs, E. M., Dannenmann, M., Kiese, R., \& Zechmeister-Boltenstern, S. (2013). Nitrous oxide emissions from soils: How well do we understand the processes and their controls? Philosophical Transactions of the Royal Society B: Biological Sciences, 368(1621). https://doi.org/10.1098/rstb.2013.0122

Butterbach-Bahl, K., Gundersen, P., Ambus, P., Augustin, J., Beier, C., Boeckx, P., Dannenmann, M., Gimeno, B. S., Ibrom, A., Kiese, R., Kitzler, B., Rees, R. M., Smith, K. A., Stevens, C., Vesala, T., \& Zechmeister-Boltenstern, S. (2011). Nitrogen processes in terrestrial ecosystems. The European Nitrogen Assessment, 6, 1-27.

Butu, M., Stef, R., Grozea, I., Corneanu, M., \& Butnariu, M. (2020) Biopesticides: Clean and viable technology for healthy environment. In: K. Hakeem, R. Bhat, \& H. Qadri (Eds.) Bioremediation and biotechnology. Springer, Cham. https://doi.org/10.1007/978-3-030-35691-0_6

Butu M., Sarac I., Corneanu M., \& Butnariu M. (2021) Advanced technologies for ecological reconstruction and bioremediation of degraded land. In: Prasad R. (Ed.) Environmental Pollution and Remediation. Environmental and Microbial Biotechnology. Springer, Singapore. https://doi.org/10. 1007/978-981-15-5499-5_4

Cardoso, O., Porcher, J. M., \& Sanchez, W. (2014). Factorydischarged pharmaceuticals could be a relevant source of aquatic environment contamination: Review of evidence and need for knowledge. Chemosphere, 115(1), 20-30. https://doi.org/10.1016/j.chemosphere.2014.02.004

Carucci, A., Cappai, G., \& Piredda, M. (2006). Biodegradability and toxicity of pharmaceuticals in biological wastewater treatment plants. Journal of Environmental Science and Health - Part A Toxic/hazardous Substances and Environmental Engineering, 41(9), 1831-1842. https:// doi.org/10.1080/10934520600779000

Casciotti, K. L., Buchwald, C., Santoro, A. E., \& Frame, C. (2011). Assessment of nitrogen and oxygen isotopic fractionation during nitrification and its expression in the marine environment. In Methods in Enzymology (1st ed., Vol. 486, Issue C). Elsevier Inc. https://doi.org/10.1016/ B978-0-12-381294-0.00011-0

Chen, S., Perathoner, S., Ampelli, C., \& Centi, G. (2019). Electrochemical dinitrogen activation: To find a sustainable way to produce ammonia. In Studies in Surface Science and Catalysis (1st ed., Vol. 178). Elsevier B.V. https:// doi.org/10.1016/B978-0-444-64127-4.00002-1 
Cui, H., Wang, S. P., Fu, J., Zhou, Z. Q., Zhang, N., \& Guo, L. (2014). Influence of ciprofloxacin on microbial community structure and function in soils. Biology and Fertility of Soils, 50(6), 939-947. https://doi.org/10.1007/ s00374-014-0914-y

Cycon, M., Borymski, S., Zolnierczyk, B., \& PiotrowskaSeget, Z. (2016). Variable effects of non-steroidal antiinflammatory drugs (NSAIDs) on selected biochemical processes mediated by soil microorganisms. Frontiers in Microbiology, 7(DEC), 1-19. https://doi.org/10.3389/ fmicb.2016.01969

Dale, O. R., Tobias, C. R., \& Song, B. (2009). Biogeographical distribution of diverse anaerobic ammonium oxidizing (anammox) bacteria in Cape Fear River Estuary. Environmental Microbiology, 11(5), 1194-1207. https://doi. org/10.1111/j.1462-2920.2008.01850.x

Davies-Barnard, T., \& Friedlingstein, P. (2020). The global distribution of biological nitrogen fixation in terrestrial natural ecosystems. Global Biogeochemical Cycles, 34(3), 1-17. https://doi.org/10.1029/2019GB006387

Devol, A. H. (2015). Denitrification, anammox, and $\mathrm{N}_{2}$ production in marine sediments. Annual Review of Marine Science, 7, 403-423. https://doi.org/10.1146/ annurev-marine-010213-135040

DeVries, S. L., Loving, M., Li, X., \& Zhang, P. (2015). The effect of ultralow-dose antibiotics exposure on soil nitrate and $\mathrm{N}_{2} \mathrm{O}$ flux. Scientific Reports, 5(August), 1-8. https:// doi.org/10.1038/srep16818

DeVries, S. L., \& Zhang, P. (2016). Antibiotics and the terrestrial nitrogen cycle: A review. Current Pollution Reports, 2(1), 51-67. https://doi.org/10.1007/s40726-016-0027-3

Dokianakis, S. N., Kornaros, M. E., \& Lyberatos, G. (2004). On the effect of pharmaceuticals on bacterial nitrite oxidation. Water Science and Technology, 50(5), 341-346. https://doi.org/10.2166/wst.2004.0347

Durso, L. M., \& Cook, K. L. (2014). Impacts of antibiotic use in agriculture: What are the benefits and risks? Current Opinion in Microbiology, 19(1), 37-44. https://doi.org/ 10.1016/j.mib.2014.05.019

Elshaghabee, F. M. F., Rokana, N., Gulhane, R. D., Sharma, C., \& Panwar, H. (2017). Bacillus as potential probiotics: Status, concerns, and future perspectives. Frontiers in Microbiology, 8(AUG), 1-15. https://doi.org/10.3389/ fmicb.2017.01490

Ergas, S. J., \& Aponte-Morales, V. (2014). Biological nitrogen removal. In Comprehensive water quality and purification (Vol. 3). Elsevier Ltd. https://doi.org/10.1016/B9780-12-382182-9.00047-5

EFSA. (2005). Opinion of the scientific panel on biological hazards on a request from the commission related to Clostridium spp in foodstuffs. The EFSA Journal, 199, $1-65$.

Fernández, I., Mosquera-Corral, A., Campos, J. L., \& Méndez, R. (2009). Operation of an anammox SBR in the presence of two broad-spectrum antibiotics. Process Biochemistry, 44(4), 494-498. https://doi.org/10.1016/j. procbio.2009.01.001

Finley, R. L., Collignon, P., Larsson, D. G. J., Mcewen, S. A., Li, X. Z., Gaze, W. H., Reid-Smith, R., Timinouni, M., Graham, D. W., \& Topp, E. (2013). The scourge of antibiotic resistance: The important role of the environment.
Clinical Infectious Diseases, 57(5), 704-710. https://doi. org/10.1093/cid/cit355

Folke, C., Polasky, S., Rockström, J., Galaz, V., Westley, F., Lamont, M., Scheffer, M., Österblom, H., Carpenter, S. R., Chapin, F. S., Seto, K. C., Weber, E. U., Crona, B. I., Daily, G. C., Dasgupta, P., Gaffney, O., Gordon, L. J., Hoff, H., Levin, S. A., ... \& Walker, B. H. (2021). Our future in the Anthropocene biosphere. In Ambio (Vol. 50, Issue 4). https://doi.org/10.1007/s13280-021-01544-8

Fowler, D., Steadman, C. E., Stevenson, D., Coyle, M., Rees, R. M., Skiba, U. M., Sutton, M. A., Cape, J. N., Dore, A. J., Vieno, M., Simpson, D., Zaehle, S., Stocker, B. D., Rinaldi, M., Facchini, M. C., Flechard, C. R., Nemitz, E., Twigg, M., Erisman, J. W., \& Galloway, J. N. (2015). Effects of global change during the 21st century onthe nitrogen cycle. Atmospheric Chemistry and Physics, 15(24), 13849-13893. https://doi.org/10.5194/ acp-15-13849-2015

Galloway, J. N., Dentener, F. J., Capone, D. G., Boyer, E. W., Howarth, R. W., Seitzinger, S. P., Asner, G. P., Cleveland, C. C., Green, P. A., Holland, E. A., Karl, D. M., Michaels, A. F., Porter, J. H., Townsend, A. R., \& Vörösmarty, C. J. (2004). Nitrogen cycles: Past, present, and future. Biogeochemistry, 70(2), 153-226. https://doi.org/10.1007/ s10533-004-0370-0

Galloway, J. N., Leach, A. M., Bleeker, A., \& Erisman, J. W. (2013). A chronology of human understanding of the nitrogen cycle. Philosophical Transactions of the Royal Society B: Biological Sciences, 368(1621). https://doi. org/10.1098/rstb.2013.0120

Gayle, B. P., Boardman, G. D., Sherrard, J. H., \& Benoit, R. E. (1989). Biological denitrification of water. Journal of Environmental Engineering, 115(5), 930-943. https:// doi.org/10.1061/(asce)0733-9372(1989)115:5(930)

Gaze, W. H., Krone, S. M., Joakim Larsson, D. G., Li, X. Z., Robinson, J. A., Simonet, P., Smalla, K., Timinouni, M., Topp, E., Wellington, E. M., Wright, G. D., \& Zhu, Y. G. (2013). Influence of humans on evolution and mobilization of environmental antibiotic resistome. Emerging Infectious Diseases, 19(7). https://doi.org/10. 3201/eid1907.120871.

Gentry, T. J., \& Zuberer, D. A. (2021). 1 - Introduction and historical perspective. In Principles and applications of soil microbiology (Third Edition), 1-22. https://doi.org/10. 1016/B978-0-12-820202-9.00001-0

Gerten, D., Heck, V., Jägermeyr, J., Bodirsky, B. L., Fetzer, I., Jalava, M., Kummu, M., Lucht, W., Rockström, J., Schaphoff, S., \& Schellnhuber, H. J. (2020). Feeding ten billion people is possible within four terrestrial planetary boundaries. Nature Sustainability, 3(3), 200-208. https:// doi.org/10.1038/s41893-019-0465-1

Gomes, M. P., de Brito, J. C. M., Carvalho Carneiro, M. M. L., Ribeiro da Cunha, M. R., Garcia, Q. S., \& Figueredo, C. C. (2018). Responses of the nitrogen-fixing aquatic fern Azolla to water contaminated with ciprofloxacin: Impacts on biofertilization. Environmental Pollution, 232, 293299. https://doi.org/10.1016/j.envpol.2017.09.054

Grenni, P., Ancona, V., \& Barra Caracciolo, A. (2018). Ecological effects of antibiotics on natural ecosystems: A review. Microchemical Journal, 136, 25-39. https://doi. org/10.1016/j.microc.2017.02.006 
Griffiths, B. S., \& Philippot, L. (2013). Insights into the resistance and resilience of the soil microbial community. FEMS Microbiology Reviews, 37(2), 112-129. https:// doi.org/10.1111/j.1574-6976.2012.00343.x

Gruber, N., \& Galloway, J. N. (2008). An Earth-system perspective of the global nitrogen cycle. Nature, 451(7176), 293-296. https://doi.org/10.1038/nature06592

Hao, D., Liu, Y., Gao, S., Arandiyan, H., Bai, X., Kong, Q., Wei, W., Shen, P. K., \& Ni, B. J. (2021). Emerging artificial nitrogen cycle processes through novel electrochemical and photochemical synthesis. Materials Today, 46(June), 212-233. https://doi.org/10.1016/j.mattod.2021.01.029

He, G., Jiang, X., Yao, L., Liu, G., Yang, Y., Jiang, Y., \& Liu, W. (2021). Effects of tetracycline on nitrogen and carbon cycling rates and microbial abundance in sediments with and without biochar amendment. Chemosphere, 270, 129509. https://doi.org/10.1016/j.chemosphere.2020.129509

He, Y., Langenhoff, A. A. M., Comans, R. N. J., Sutton, N. B., \& Rijnaarts, H. H. M. (2018). Effects of dissolved organic matter and nitrification on biodegradation of pharmaceuticals in aerobic enrichment cultures. Science of the Total Environment, 630, 1335-1342. https://doi. org/10.1016/j.scitotenv.2018.02.180

Herridge, D. F., Peoples, M. B., \& Boddey, R. M. (2008). Global inputs of biological nitrogen fixation in agricultural systems. Plant and Soil, 311(1-2), 1-18. https://doi. org/10.1007/s11104-008-9668-3

Hijosa-Valsero, M., Reyes-Contreras, C., Domínguez, C., Bécares, E., \& Bayona, J. M. (2016). Behaviour of pharmaceuticals and personal care products in constructed wetland compartments: Influent, effluent, pore water, substrate and plant roots. Chemosphere, 145, 508-517. https://doi.org/10.1016/j.chemosphere.2015.11.090

Hirsch, P. R., \& Mauchline, T. H. (2015). The importance of the microbial $\mathrm{N}$ cycle in soil for crop plant nutrition. In Advances in Applied Microbiology (Vol. 93). Elsevier Ltd. https://doi.org/10.1016/bs.aambs.2015.09.001

Hou, L., Yin, G., Liu, M., Zhou, J., Zheng, Y., Gao, J., Zong, H., Yang, Y., Gao, L., \& Tong, C. (2015). Effects of sulfamethazine on denitrification and the associated N2O release in estuarine and coastal sediments. Environmental Science and Technology, 49(1), 326-333. https://doi. org/10.1021/es504433r

Hu, H. W., \& He, J. Z. (2017). Comammox-A newly discovered nitrification process in the terrestrial nitrogen cycle. Journal of Soils and Sediments, 17(12), 2709-2717. https://doi.org/10.1007/s11368-017-1851-9

Hu, H. W., Xu, Z. H., \& He, J. Z. (2014). Ammonia-oxidizing archaea play a predominant role in acid soil nitrification. In Advances in agronomy (1st ed., Vol. 125). Elsevier Inc. https://doi.org/10.1016/B978-0-12-800137-0. 00006-6

Humbert, S., Tarnawski, S., Fromin, N., Mallet, M. P., Aragno, M., \& Zopfi, J. (2010). Molecular detection of anammox bacteria in terrestrial ecosystems: Distribution and diversity. ISME Journal, 4(3), 450-454. https://doi.org/10. 1038/ismej.2009.125

Humbert, S., Zopfi, J., \& Tarnawski, S. E. (2012). Abundance of anammox bacteria in different wetland soils. Environmental Microbiology Reports, 4(5), 484-490. https://doi.org/ 10.1111/j.1758-2229.2012.00347.x
Izaurralde, R. C., McGill, W. B., \& Williams, J. R. (2012). Development and application of the epic model for carbon cycle, greenhouse gas mitigation, and biofuel studies. Elsevier Inc. https://doi.org/10.1016/B978-0-12386897-8.00017-6

Jarvis, S., Hutchings, N., Brentrup, F., Olesen, J. E., \& van de Hoek, K. W. (2011). Nitrogen flows in farming systems across Europe. In: The European Nitrogen Assessment: Sources, effects and policy perspectives. Cambridge University Press, 211-228. https://doi.org/10.1017/ CBO9780511976988.013

Jetten, M. S. M., Niftrik, L. Van, Strous, M., Kartal, B., Keltjens, J. T., \& Op Den Camp, H. J. M. (2009). Biochemistry and molecular biology of anammox bacteria biochemistry and molecular biology of anammox bacteria M.S.M. Jetten et al. Critical Reviews in Biochemistry and Molecular Biology, 44(2-3), 65-84. https://doi.org/ 10.1080/10409230902722783

Kartal, B., Rattray, J., van Niftrik, L. A., van de Vossenberg, J., Schmid, M. C., Webb, R. I., Schouten, S., Fuerst, J. A., Damsté, J. S., Jetten, M. S. M., \& Strous, M. (2007). Candidatus "Anammoxoglobus propionicus" a new propionate oxidizing species of anaerobic ammonium oxidizing bacteria. Systematic and Applied Microbiology, 30(1), 39-49. https://doi.org/10.1016/j.syapm.2006.03. 004

Kartal, B., Van Niftrik, L., Rattray, J., Van De Vossenberg, J. L. C. M., Schmid, M. C., Sinninghe Damsté, J., Jetten, M. S. M., \& Strous, M. (2008). Candidatus "Brocadia fulgida": An autofluorescent anaerobic ammonium oxidizing bacterium. FEMS Microbiology Ecology, 63(1), 46-55. https://doi.org/10.1111/j.1574-6941.2007.00408.x

Katipoglu-Yazan, T., Pala-Ozkok, I., Ubay-Cokgor, E., \& Orhon, D. (2013). Acute impact of erythromycin and tetracycline on the kinetics of nitrification and organic carbon removal in mixed microbial culture. Bioresource Technology, 144, 410-419. https://doi.org/10.1016/j. biortech.2013.06.121

Kay, P., Blackwell, P. A., \& Boxall, A. B. A. (2004). Fate of veterinary antibiotics in a macroporous tile drained clay soil. Environmental Toxicology and Chemistry, 23(5), 1136-1144. https://doi.org/10.1897/03-374

Kendall, C., Doctor, D. H., \& Young, M. B. (2013). Environmental isotope applications in hydrologic studies. In Treatise on geochemistry: Second Edition (2nd ed., Vol. 7). Published by Elsevier Inc. https://doi.org/10.1016/B978-008-095975-7.00510-6

Klaver, A. L., \& Matthews, R. A. (1994). Effects of oxytetracycline on nitrification in a model aquatic system. Aquaculture, 123(3-4), 237-247. https://doi.org/10.1016/00448486(94)90062-0

Köpping, I., McArdell, C. S., Borowska, E., Böhler, M. A., \& Udert, K. M. (2020). Removal of pharmaceuticals from nitrified urine by adsorption on granular activated carbon. Water Research X, 9. https://doi.org/10.1016/j.wroa. 2020.100057

Kotzerke, A., Sharma, S., Schauss, K., Heuer, H., ThieleBruhn, S., Smalla, K., Wilke, B. M., \& Schloter, M. (2008). Alterations in soil microbial activity and $\mathrm{N}$-transformation processes due to sulfadiazine loads in 
pig-manure. Environmental Pollution, 153(2), 315-322. https://doi.org/10.1016/j.envpol.2007.08.020

Kowalchuk, G. A., \& Stephen, J. R. (2001). Ammonia-oxidizing bacteria: A model for molecular microbial ecology. Annual Review of Microbiology, 55, 485-529. https://doi.org/10. 1146/annurev.micro.55.1.485

Kumar, K., Gupta, C., \& S., Chander, Y., \& Singh, A. K. (2005). Antibiotic use in agriculture and its impact on the terrestrial environment. Advances in Agronomy, 87(05), 1-54. https://doi.org/10.1016/S0065-2113(05)87001-4

Kuypers, M. M. M., Lavik, G., Woebken, D., Schmid, M., Fuchs, B. M., Amann, R., Jørgensen, B. B., \& Jetten, M. S. M. (2005). Massive nitrogen loss from the Benguela upwelling system through anaerobic ammonium oxidation. Proceedings of the National Academy of Sciences of the United States of America, 102(18), 6478-6483. https://doi.org/10. 1073/pnas.0502088102

Kuypers, M. M. M., Marchant, H. K., \& Kartal, B. (2018). The microbial nitrogen-cycling network. Nature Reviews Microbiology, 16(5), 263-276. https://doi.org/10.1038/ nrmicro.2018.9

Lam, P., Lavik, G., Jensen, M. M., De Van Vossenberg, J., Schmid, M., Woebken, D., Gutiérrez, D., Amann, R., Jetten, M. S. M., \& Kuypers, M. M. M. (2009). Revising the nitrogen cycle in the Peruvian oxygen minimum zone. Proceedings of the National Academy of Sciences of the United States of America, 106(12), 4752-4757. https://doi.org/10.1073/pnas.0812444106

Laverman, A. M., Cazier, T., Yan, C., Roose-Amsaleg, C., Petit, F., Garnier, J., \& Berthe, T. (2015). Exposure to vancomycin causes a shift in the microbial community structure without affecting nitrate reduction rates in river sediments. Environmental Science and Pollution Research, 22(18), 13702-13709. https://doi.org/10.1007/ s11356-015-4159-6

Li, G. F., Huang, B. C., Zhang, Z. Z., Cheng, Y. F., Fan, N. S., \& Jin, R. C. (2019). Recent advances regarding the impacts of engineered nanomaterials on the anaerobic ammonium oxidation process: Performances and mechanisms. Environmental Science: Nano, 6(12), 3501-3512. https://doi.org/10.1039/c9en01009b

Li, W., Shi, C., Yu, Y., Ruan, Y., Kong, D., Lv, X., Xu, P., Awasthi, M. K., \& Dong, M. (2021). Interrelationships between tetracyclines and nitrogen cycling processes mediated by microorganisms: A review. Bioresource Technology, 319(June 2020), 124036. https://doi.org/10. 1016/j.biortech.2020.124036

Long, A., Heitman, J., Tobias, C., Philips, R., \& Song, B. (2013). Co-occurring anammox, denitrification, and codenitrification in agricultural soils. Applied and Environmental Microbiology, 79(1), 168-176. https://doi.org/ 10.1128/AEM.02520-12

Lopez, C., Nnorom, M. A., Tsang, Y. F., \& Knapp, C. W. (2021). Pharmaceuticals and personal care products' (PPCPs) impact on enriched nitrifying cultures. Environmental Science and Pollution Research. https://doi.org/ 10.1007/s11356-021-14696-7

Lotti, T., Cordola, M., Kleerebezem, R., Caffaz, S., Lubello, C., \& Van Loosdrecht, M. C. M. (2012). Inhibition effect of swine wastewater heavy metals and antibiotics on anammox activity. Water Science and Technology, 66(7), 1519-1526. https://doi.org/10.2166/wst.2012.344

Luo, Y., Melillo, J., Niu, S., Beier, C., Clark, J. S., Classen, A. T., Davidson, E., Dukes, J. S., Evans, R. D., Field, C. B., Czimczik, C. I., Keller, M., Kimball, B. A., Kueppers, L. M., Norby, R. J., Pelini, S. L., Pendall, E., Rastetter, E., Six, J., ... \& Torn, M. S. (2011). Coordinated approaches to quantify long-term ecosystem dynamics in response to global change. Global Change Biology, 17(2), 843-854. https://doi.org/10.1111/j.1365-2486.2010.02265.x

Marino, R. W., \& Howarth, R. (2009). Nitrogen fixation: Introduction to biological nitrogen fixation in aquatic systems. Inorganic Chemicals, 65-72.

Marino, R. W., \& Howarth, R. (2014). Nitrogen fixation in freshwater and saline waters. Reference Module in Earth Systems and Environmental Sciences. https://doi.org/10. 1016/B978-0-12-409548-9.09402-1

Martens, D. A. (2004). Denitrification. Encyclopedia of Soils in the Environment, 4, 378-382. https://doi.org/10.1016/ B0-12-348530-4/00138-7

Mekonnen, E., Kebede, A., Nigussie, A., Kebede, G., \& Tafesse, M. (2021). Isolation and characterization of urease-producing soil bacteria. International Journal of Microbiology, 2021. https://doi.org/10.1155/2021/ 8888641

Moore, T. A., Xing, Y., Lazenby, B., Lynch, M. D. J., Schiff, S., Robertson, W. D., Timlin, R., Lanza, S., Ryan, M. C., Aravena, R., Fortin, D., Clark, I. D., \& Neufeld, J. D. (2011). Prevalence of anaerobic ammonium-oxidizing bacteria in contaminated groundwater. Environmental Science and Technology, 45(17), 7217-7225. https://doi. org/10.1021/es201243t

Nandanwar, S., Yele, Y., Dixit, A., Goss-Souza, D., Singh, R., Shanware, A., \& Kharbikar, L. (2020). Effects of pesticides, temperature, light, and chemical constituents of soil on nitrogen fixation. Nitrogen Fixation, 1-8. https://doi.org/10.5772/ intechopen. 86128

Nardi, J. B., Mackie, R. I., \& Dawson, J. O. (2002). Could microbial symbionts of arthropod guts contribute significantly to nitrogen fixation in terrestrial ecosystems? Journal of Insect Physiology, 48(8), 751-763. https://doi. org/10.1016/S0022-1910(02)00105-1

O’Neil, J. M., \& Capone, D. G. (2008). Nitrogen cycling in coral reef environments. In Nitrogen in the Marine Environment. https://doi.org/10.1016/B978-0-12-372522-6. 00021-9

Ory, J., Bricheux, G., Togola, A., Bonnet, J. L., DonnadieuBernard, F., Nakusi, L., Forestier, C., \& Traore, O. (2016). Ciprofloxacin residue and antibiotic-resistant biofilm bacteria in hospital effluent. Environmental Pollution, 214, 635-645. https://doi.org/10.1016/j.envpol. 2016.04.033

Park, H. I., Choi, Y. J., \& Pak, D. (2005). Autohydrogenotrophic denitrifying microbial community in a glass beads biofilm reactor. Biotechnology Letters, 27(13), 949-953. https:// doi.org/10.1007/s10529-005-7654-X

Park, J., Park, S., \& Kim, M. (2014). Anaerobic degradation of amino acids generated from the hydrolysis of sewage sludge. Environmental Technology (united Kingdom), 35(9), 1133-1139. https://doi.org/10.1080/09593330. 2013.863951 
Pashaei, R., Gholizadeh, M., Iran, K. J., \& Hanifi, A. (2015). The effects of oil spills on ecosystem at the Persian Gulf. International Journal of Review in Life Sciences, 5(3), 82-89. https://doi.org/10.13140/RG.2.1.2239. 3684

Patrolecco, L., Capri, S., \& Ademollo, N. (2015). Occurrence of selected pharmaceuticals in the principal sewage treatment plants in Rome (Italy) and in the receiving surface waters. Environmental Science and Pollution Research, 22(8), 5864-5876. https://doi.org/10.1007/ s11356-014-3765-Z

Peng, J., Wang, X., Yin, F., \& Xu, G. (2019). Characterizing the removal routes of seven pharmaceuticals in the activated sludge process. Science of the Total Environment, 650, 2437-2445. https://doi.org/10.1016/j.scitotenv. 2018.10.004

Philippot, L., Hallin, S., \& Schloter, M. (2007). Ecology of denitrifying prokaryotes in agricultural soil. Advances in Agronomy, 96(07), 249-305. https://doi.org/10.1016/ S0065-2113(07)96003-4

Podgórska, B., \& Mudryk, Z. J. (2007). Physiological properties of bacteria inhabiting polluted and unpolluted marine sandy beaches (southern Baltic Sea). Polish Journal of Ecology, 55(1), 15-26.

Prosser, J. I. (2007). The ecology of nitrifying bacteria. Biology of the Nitrogen Cycle, 2, 223-243. https://doi.org/10. 1016/B978-044452857-5.50016-3

Quan, Z. X., Rhee, S. K., Zuo, J. E., Yang, Y., Bae, J. W., Park, J. R., Lee, S. T., \& Park, Y. H. (2008). Diversity of ammonium-oxidizing bacteria in a granular sludge anaerobic ammonium-oxidizing (anammox) reactor. Environmental Microbiology, 10(11), 3130-3139. https://doi.org/ 10.1111/j.1462-2920.2008.01642.x

Quesada, H. B., Baptista, A. T. A., Cusioli, L. F., Seibert, D., de Oliveira Bezerra, C., \& Bergamasco, R. (2019). Surface water pollution by pharmaceuticals and an alternative of removal by low-cost adsorbents: A review. Chemosphere, 222, 766-780. https://doi.org/10.1016/j. chemosphere.2019.02.009

Radke, M., Ulrich, H., Wurm, C., \& Kunkel, U. (2010). Dynamics and attenuation of acidic pharmaceuticals along a river stretch. Environmental Science and Technology, 44(8), 2968-2974. https://doi.org/10.1021/ es903091z

Revellin, C., Hartmann, A., Solanas, S., \& Topp, E. (2018). Long-term exposure of agricultural soil to veterinary antibiotics changes the population structure of symbiotic nitrogen-fixing rhizobacteria occupying nodules of soybeans (Glycine max). Applied and Environmental Microbiology, 84(9). https://doi.org/10.1128/AEM.00109-18

Rich, J. J., Dale, O. R., Song, B., \& Ward, B. B. (2008). Anaerobic ammonium oxidation (anammox) in Chesapeake Bay sediments. Microbial Ecology, 55(2), 311-320. https:// doi.org/10.1007/s00248-007-9277-3

Roh, H., Subramanya, N., Zhao, F., Yu, C. P., Sandt, J., \& Chu, K. H. (2009). Biodegradation potential of wastewater micropollutants by ammonia-oxidizing bacteria. Chemosphere, 77(8), 1084-1089. https://doi.org/10.1016/j. chemosphere.2009.08.049

Roose-Amsaleg, C., \& Laverman, A. M. (2016). Do antibiotics have environmental side-effects? Impact of synthetic antibiotics on biogeochemical processes. Environmental Science and Pollution Research, 23(5), 4000-4012. https://doi.org/10.1007/s11356-015-4943-3

Rosca, V., Duca, M., DeGroot, M. T., \& Koper, M. T. M. (2009). Nitrogen cycle electrocatalysis. Chemical Reviews, 109(6), 2209-2244. https://doi.org/10.1021/ cr8003696

Sato, Y., Ohta, H., Yamagishi, T., Guo, Y., Nishizawa, T., Habibur Rahman, M., Kuroda, H., Kato, T., Saito, M., Yoshinaga, I., Inubushi, K., \& Suwa, Y. (2012). Detection of anammox activity and 16S rRNA genes in ravine paddy field soil. Microbes and Environments, 27(3), 316-319. https://doi.org/10.1264/jsme2.ME11330

Schmid, M. C., Risgaard-Petersen, N., Van De Vossenberg, J., Kuypers, M. M. M., Lavik, G., Petersen, J., Hulth, S., Thamdrup, B., Canfield, D., Dalsgaard, T., Rysgaard, S., Sejr, M. K., Strous, M., Op Den Camp, H. J. M., \& Jetten, M. S. M. (2007). Anaerobic ammonium-oxidizing bacteria in marine environments: Widespread occurrence but low diversity. Environmental Microbiology, 9(6), 1476-1484. https://doi.org/10.1111/j.1462-2920.2007. 01266.x

Schmid, M., Twachtmann, U., Klein, M., Strous, M., Juretschko, S., Jetten, M., Metzger, J. W., Schleifer, K. H., \& Wagner, M. (2000). Molecular evidence for genus level diversity of bacteria capable of catalyzing anaerobic ammonium oxidation. Systematic and Applied Microbiology, 23(1), 93-106. https://doi.org/10.1016/S07232020(00)80050-8

Schmid, M., Walsh, K., Webb, R., Rijpstra, W. I. C., Van De Pas-Schoonen, K., Verbruggen, M. J., Hill, T., Moffett, B., Fuerst, J., Schouten, S., Damsté, J. S. S., Harris, J., Shaw, P., Jetten, M., \& Strous, M. (2003). Candidatus "Scalindua brodae", sp. nov., Candidatus "Scalindua wagneri", sp. nov., two new species of anaerobic ammonium oxidizing bacteria. Systematic and Applied Microbiology, 26(4), 529-538. https://doi.org/10.1078/ 072320203770865837

Schubert, C. J., Durisch-Kaiser, E., Wehrli, B., Thamdrup, B., Lam, P., \& Kuypers, M. M. M. (2006). Anaerobic ammonium oxidation in a tropical freshwater system (Lake Tanganyika). Environmental Microbiology, 8(10), 18571863. https://doi.org/10.1111/j.1462-2920.2006.01074.x

Sguanci, S., Lotti, T., Caretti, C., Caffaz, S., Dockhorn, T., \& Lubello, C. (2017). Inhibitory effects of veterinary antibiotics on anammox activity: Short- and long-term tests. Environmental Technology (united Kingdom), 38(21), 2661-2667. https://doi.org/10.1080/09593330. 2016.1272640

Simek, M., Jisova, L., \& Hopkins, D. W. (2002). What is the so-called optimum $\mathrm{pH}$ for denitrification in soil? Soil Biology \& Biochemistry, 34(9), 1227-1234. https://doi. org/10.1016/S0038-0717(02)00059-7

Sofo, A., Zanella, A., \& Ponge, J. F. (2021). Soil quality and fertility in sustainable agriculture, with a contribution to the biological classification of agricultural soils. Soil Use and Management, October 2020, 1-28. https://doi.org/10.1111/ sum.12702

Soliman, M., \& Eldyasti, A. (2018). Ammonia-oxidizing bacteria (AOB): Opportunities and applications-A review. In Reviews in Environmental Science and Biotechnology 
(Vol. 17, Issue 2). Springer Netherlands. https://doi.org/ 10.1007/s11157-018-9463-4

Sprent, J. I., Ardley, J., \& James, E. K. (2017). Biogeography of nodulated legumes and their nitrogen-fixing symbionts. New Phytologist, 215(1), 40-56. https://doi.org/10. 1111/nph.14474

Stieglmeier, M., Wirth, R., Kminek, G., \& Moissl-Eichinger, C. (2009). Cultivation of anaerobic and facultatively anaerobic bacteria from spacecraft-associated clean rooms. Applied and Environmental Microbiology, 75(11), 34843491. https://doi.org/10.1128/AEM.02565-08

Strous, M., Jhon, A. F., Evelien, H. M. K., Susanne, L., Gerard, M., van de Katinka, T., \& P.-S., Richard, W., J. Gijs, K., \& Mike, S. M. J. (1999). Missing lithotroph identified as new planctomycete. Nature, 400(July), 446-449.

Sutton, M. A., Howard, C. M., Erisman, J. W., Billen, G., \& Bleeker, A. (2011). The European Nitrogen Assessment: Front matter. The European Nitrogen Assessment.

Tang, C. J., Zheng, P., Chen, T. T., Zhang, J. Q., Mahmood, Q., Ding, S., Chen, X. G., Chen, J. W., \& Wu, D. T. (2011). Enhanced nitrogen removal from pharmaceutical wastewater using SBA-ANAMMOX process. Water Research, 45(1), 201-210. https://doi.org/10.1016/j.watres.2010.08. 036

Thamdrup, B., Dalsgaard, T., Jensen, M. M., Ulloa, O., Farías, L., \& Escribano, R. (2006). Anaerobic ammonium oxidation in the oxygen-deficient waters off northern Chile. Limnology and Oceanography, 51(5), 2145-2156. https://doi.org/10.4319/lo.2006.51.5.2145

Toth, J. D., Feng, Y., \& Dou, Z. (2011). Veterinary antibiotics at environmentally relevant concentrations inhibit soil iron reduction and nitrification. Soil Biology and Biochemistry, 43(12), 2470-2472. https://doi.org/10.1016/j. soilbio.2011.09.004

Trimmer, M., Nicholls, J. C., \& Deflandre, B. (2003). Anaerobic ammonium oxidation measured in sediments along the Thames Estuary. United Kingdom. Applied and Environmental Microbiology, 69(11), 6447-6454. https://doi. org/10.1128/AEM.69.11.6447-6454.2003

Underwood, J. C., Harvey, R. W., Metge, D. W., Repert, D. A., Baumgartner, L. K., Smith, R. L., Roane, T. M., \& Barber, L. B. (2011). Effects of the antimicrobial sulfamethoxazole on groundwater bacterial enrichment. Environmental Science and Technology, 45(7), 30963101. https://doi.org/10.1021/es103605e

Van Den Berg, N. L., \& Ashmore, M. (2008). Introduction nitrogen pollution in a global perspective nitrogen ecotoxicity in terrestrial ecosystems. Encyclopedia of Ecology, 2518-2526.

Van Groenigen, J. W., Huygens, D., Boeckx, P., Kuyper, T. W., Lubbers, I. M., Rütting, T., \& Groffman, P. M. (2015). The soil N cycle: New insights and key challenges. The Soil, 1(1), 235-256. https://doi.org/10.5194/soil-1-235-2015

Van Groenigen, K. J., Six, J., Hungate, B. A., De Graaff, M. A., Van Breemen, N., \& Van Kessel, C. (2006). Element interactions limit soil carbon storage. Proceedings of the National Academy of Sciences of the United States of America, 103(17), 6571-6574. https://doi.org/10.1073/ pnas.0509038103

Vardanian, A., Kurzbaum, E., Farber, Y., Butnariu, M., \& Armon, R. (2018). Facilitated enumeration of the silicate bacterium Paenibacillus mucilaginosus comb. nov. (formerly Bacillus mucilaginosus) via tetrazolium chloride incorporation into a double agar-based solid growth medium. Folia Microbiologica, 63(3), 401-404. https:// doi.org/10.1007/s12223-017-0567-y

Verlicchi, P., Al Aukidy, M., \& Zambello, E. (2015). What have we learned from worldwide experiences on the management and treatment of hospital effluent? - An overview and a discussion on perspectives. Science of the Total Environment, 514, 467-491. https://doi.org/10. 1016/j.scitotenv.2015.02.020

Vitousek, P. M., Hättenschwiler, S., Olander, L., \& Allison, S. (2002). Nitrogen and nature. Ambio, 31(2), 97-101. https://doi.org/10.1579/0044-7447-31.2.97

Vitousek, P. M., Menge, D. N. L., Reed, S. C., \& Cleveland, C. C. (2013). Biological nitrogen fixation: Rates, patterns and ecological controls in terrestrial ecosystems. Philosophical Transactions of the Royal Society B: Biological Sciences, 368(1621). https://doi.org/10.1098/rstb.2013. 0119

Voss, M., Bange, H. W., Dippner, J. W., Middelburg, J. J., Montoya, J. P., \& Ward, B. (2013). The marine nitrogen cycle: Recent discoveries, uncertaintiesand the potential relevance of climate change. Philosophical Transactions of the Royal Society B: Biological Sciences, 368(1621). https://doi.org/10.1098/rstb.2013.0121

Ward, B. B. (2011). Measurement and distribution of nitrification rates in the oceans. In Methods in Enzymology (1st ed., Vol. 486, Issue C). Elsevier Inc. https://doi.org/10. 1016/B978-0-12-381294-0.00013-4

Ward, B. B., \& Zafiriou, O. C. (1988). Nitrification and nitric oxide in the oxygen minimum of the eastern tropical North Pacific. Deep Sea Research Part a, Oceanographic Research Papers, 35(7), 1127-1142. https://doi.org/10. 1016/0198-0149(88)90005-2

Ward, B. B. (2008). Chapter 5 - Nitrification in marine systems. In Nitrogen in the Marine Environment. https://doi. org/10.1016/B978-0-12-372522-6.00005-0

Woodmansee, R. G., Dodd, J. L., Bowman, R. A., Clark, F. E., \& Dickinson, C. E. (1978). Nitrogen budget of a shortgrass prairie ecosystem. Oecologia, 34(3), 363-376. https://doi.org/10.1007/BF00344913

Wu, J., Hong, Y., Chang, X., Jiao, L., Li, Y., Liu, X., Xie, H., \& Gu, J. D. (2019). Unexpectedly high diversity of anammox bacteria detected in deep-sea surface sediments of the South China Sea. FEMS Microbiology Ecology, 95(3). https://doi.org/10.1093/femsec/fiz013.

Xi, D., Bai, R., Zhang, L., \& Fanga, Y. (2016). Contribution of anammox to nitrogen removal in two temperate forest soils. Applied and Environmental Microbiology, 82(15), 4602-4612. https://doi.org/10.1128/AEM.00888-16

Yang, J. F., Ying, G. G., Liu, S., Zhou, L. J., Zhao, J. L., Tao, R., \& Peng, P. A. (2012). Biological degradation and microbial function effect of norfloxacin in a soil under different conditions. Journal of Environmental Science and Health - Part B Pesticides, Food Contaminants, and Agricultural Wastes, 47(4), 288-295. https://doi.org/10. 1080/03601234.2012.638886

Zehr, J. P., \& Kudela, R. M. (2011). Nitrogen cycle of the open ocean: From genes to ecosystems. Annual Review 
of Marine Science, 3, 197-225. https://doi.org/10.1146/ annurev-marine-120709-142819

Zhang, Q. Q., Ji, X. M., Tian, G. M., \& Jin, R. C. (2021). Evolution of microbial community and antibiotic resistance genes in anammox process stressed by oxytetracycline and copper. Bioresource Technology, 319(September 2020), 124106. https://doi.org/10.1016/j.biortech.2020. 124106

Zhang, X., Han, H., Zheng, X., Yu, T., \& Chen, Y. (2019a). Tetracycline-induced effects on the nitrogen transformations in sediments: Roles of adsorption behavior and bacterial activity. Science of the Total Environment, 695, 133811. https://doi.org/10.1016/j.scitotenv.2019.133811

Zhang, X., Chen, Z., Ma, Y., Zhang, N., Pang, Q., Xie, X., Li, Y., \& Jia, J. (2019b). Response of Anammox biofilm to antibiotics in trace concentration: Microbial activity, diversity and antibiotic resistance genes. Journal of Hazardous Materials, 367(September 2018), 182-187. https://doi.org/ 10.1016/j.jhazmat.2018.12.082

Zhang, Y., Ruan, X. H., Op Den Camp, H. J. M., Smits, T. J. M., Jetten, M. S. M., \& Schmid, M. C. (2007). Diversity and abundance of aerobic and anaerobic ammoniumoxidizing bacteria in freshwater sediments of the Xinyi River (China). Environmental Microbiology, 9(9), 23752382. https://doi.org/10.1111/j.1462-2920.2007.01357.X

Zhu, G., Song, X., Ju, X., Zhang, J., Müller, C., SylvesterBradley, R., Thorman, R. E., Bingham, I., \& Rees, R. M.
(2019). Gross N transformation rates and related N2O emissions in Chinese and UK agricultural soils. Science of the Total Environment, 666, 176-186. https://doi.org/ 10.1016/j.scitotenv.2019.02.241

Zhu, G., Wang, S., Wang, Y., Wang, C., Risgaard-Petersen, N., Jetten, M. S., \& Yin, C. (2011). Anaerobic ammonia oxidation in a fertilized paddy soil. ISME Journal, 5(12), 1905-1912. https://doi.org/10.1038/ismej.2011.63

Zhu, J., Wang, Q., Yuan, M., Tan, G. Y. A., Sun, F., Wang, C., Wu, W., \& Lee, P. H. (2016). Microbiology and potential applications of aerobic methane oxidation coupled to denitrification (AME-D) process: A review. Water Research, 90, 203-215. https://doi.org/10.1016/j.watres. 2015.12.020

Zuccato, E., Castiglioni, S., Bagnati, R., Melis, M., \& Fanelli, R. (2010). Source, occurrence and fate of antibiotics in the Italian aquatic environment. Journal of Hazardous Materials, 179(1-3), 1042-1048. https://doi.org/10. 1016/j.jhazmat.2010.03.110

Publisher's Note Springer Nature remains neutral with regard to jurisdictional claims in published maps and institutional affiliations. 